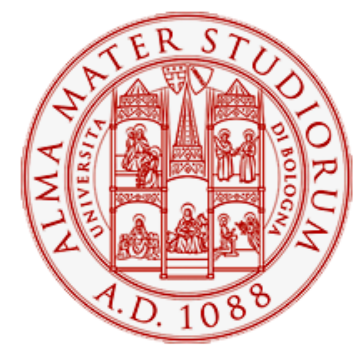

Alma Mater Studiorum - Università di Bologna DEPARTMENT OF ECONOMICS






\title{
Does the Support of Innovative Clusters Sustainably Foster R\&D Activity? Evidence from the German BioRegio and BioProfile Contests
}

\author{
Dirk Engel* $^{*} \quad$ Timo Mitze ${ }^{* *} \quad$ Roberto Patuelli*** Janina Reinkowski ${ }^{\S}$
}

First version: June 2010; This version: January 2011

\begin{abstract}
In this paper, we evaluate the $R \& D$ enhancing effects of two large public grant schemes aiming at encouraging the performance of firms organized in clusters. These are Germany's well known BioRegio and BioProfile contests for which we compare the research performance of winning regions in contrast with non-winning and non-participating comparison regions. We apply Difference-inDifference estimation techniques in a generalized linear model framework, which allows to control for different initial regional conditions in the biotechnology related R\&D activity. Our econometric findings support the view that winners generally outperform non-winning participants during the treatment period, thus indicating that exclusive funding as well as the stimulating effect of being a "winner" seems to work in the short-term. In contrast, no indirect impacts stemming from a potential mobilizing effect of the contest approaches have been detected. Also, we find only limited evidence for long-term effects of public R\&D grants in the post-treatment period. The results of our analysis remain stable if we additionally augment the model to account for the particular role of spatial dependence in the $\mathrm{R} \& \mathrm{D}$ outcome variables.
\end{abstract}

JEL-Classification: O38, R38, C23

Keywords: Biotechnology; R\&D Policies; Cluster; Diff-in-Diff Estimation

*University of Applied Science Stralsund\& RWI, Email: dirk.engel@fh-stralsund.de.

** RWI \& Ruhr University Bochum, E-mail: Mitze@rwi-essen.de. Corresponding author; Postal Address: Hohenzollernstr. 1-3, 45128 Essen/Germany, Tel.: +49/201/8149223, Fax: +49/201/8149200. Earlier versions of this paper have been presented at the GfR Summer Conference 2010 in Hannover, the RWI Therapy Summer Seminar 2010 and the IWH/University Jena Joint International Workshop on "Which regions benefit from emerging new industries? Evidence from photovoltaic and other high-tech industries". The authors wish to thank Uwe Cantner, Dirk Fornahl, Joel Stiebale and further participants of the above events for helpful comments and advices. Also special thanks to Björn Alecke for providing some of the data used for this research, as well as Karl-Heinz Herlitschke for his efforts to extract and prepare information from the ESPACE database.

*** Department of Economics, Faculty of Economics-Rimini, University of Bologna; Institute for Economic Research (IRE), University of Lugano; The Rimini Centre for Economic Analysis (RCEA), Email: roberto.patuelli@unibo.it

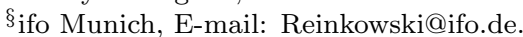




\section{Introduction}

Throughout the 1990s, the design of the German national research and development $(\mathrm{R} \& \mathrm{D})$ policy experienced a paradigmatic shift from standard grant schemes to a regionalization of $R \& D$ policy. In this context, the latter principle can be best described as the political concept of providing preferred access to public funding schemes for selected regions, which are expected to yield the highest social return on funding. Since grant allocation according to this rule requires knowledge about the endowment and distribution of regional competencies, so-called contests of cooperation have been established in order to encourage regional actors to jointly participate and signal their common competencies.

Among the first programmes highlighting this competitive spirit were the BioRegio and BioProfile contests starting in 1997 and 1999, respectively. Both programmes aimed to foster commercialization in biotechnology and to make Germany the number one European country in the sector (see Eickelpasch and Fritsch 2005). The currently ongoing Leading Edge Cluster contest (in German, Spitzencluster-Wettbewerb) of the German Federal Ministry for Research and Education is a prominent successor to this idea, which widens the scope of funding of innovative clusters to other high-tech sectors beside biotechnology.

Although there is by now a huge stock of theoretical and empirical literature on the effects of geographical concentration of the main actors in regional and/or sectoral innovation systems, almost nothing is known about the effects of stimulating the $R \& D$ activity in selected regions through such contests of cooperation. In this paper, we thus aim to evaluate the research performance of winners relative to two comparison groups, namely participating (but non-winning) and non-participating regions of the BioRegio and BioProfile contests, for the periods during and after funding. As outcome variables of interest, we analyse the regions' patenting activity and their expected ability to raise public R\&D funds due to the status of being a 'winner' in the respective contest. ${ }^{1}$ Our database covers all 426 German NUTS-3 districts (Kreise) for the period 1991 to 2007.

From a methodological point of view, we estimate a set of Difference-in-Difference (DiD) models based on Poisson and Zero-inflated Poisson regressions, where the latter account for excessive zeros in the outcome variable (in particular: the number of research projects raised through public funding, as well as the number of patent applications for all German NUTS-3 districts). To account for the likely role of spatial dependence in the dataset, we also apply spatial filtering techniques to the model in a robustness check.

The remainder of the paper is structured as follows. In section 2 we briefly discuss the

\footnotetext{
${ }^{1}$ Using patenting activity we explicitly account for the fact that patent applications are typically made with a time lag relative to the received funding.
} 
theoretical background. Section 3 sketches the database, and presents several descriptive findings, followed by a brief summary of the estimation strategy. The estimation results are discussed in Section 4. Section 5 reports the outcome of the augmented modelling approach, which additionally controls for spatial dependence in the outcome variable. Finally, Section 6 concludes the paper.

\section{The regionalization of $R \& D$ policy}

\section{$2.1 \quad$ Rationales}

The $R \& D$ regionalization policy described above fits quite closely with the theoretical expectation that the extent of externalities, technological change and commercialization of innovative ideas are all positively affected by the geographical concentration of public and private research actors who share interests in similar fields of technology. ${ }^{2}$ The positive effects of local agglomerations have their roots in Marshall's (1890) externalities based on specialized labour pools, input sharing and knowledge spillovers. Since biotechnology is a dynamic research field, new scientific insights into technologies and procedures are vital to a firm's survival and success. Therefore, access to talented and well-trained scientists like postgraduate students and laboratory personnel is of particular importance. Almeida and Kolgut (1999) show that regional agglomeration of knowledge both intra- and intersectorally ("knowledge clusters"), access to scientific facilities, and a suitably trained labour pool may be favourable for firms. Entrepreneurs of biotechnological ventures who are embedded in these networks have the chance to take advantage of access to knowledge, financial institutions, and so on.

While the positive effects of local agglomerations for knowledge intensive industries might be clear from a theoretical point of view, it is not easy to identify the causal effect of geographical proximity on R\&D activity. Starting from the influential work of Acs et al. (1993), Jaffe et al. (1993), Audretsch and Feldman (1996) and Anselin et al. (1997), there is a growing literature aiming to empirically test the transmission channels from clustered firms to enhanced R\&D and innovation activity and finally productivity growth. Acs et al. (1993), for instance, estimate production functions for US data and find that, beside standard input factors, the geographical position in a cluster matters strongly. Jaffe et al. (1993) find that patent applications are cited to a greater extent by actors in geographical proximity to the inventor rather than from actors far away from

\footnotetext{
${ }^{2}$ Although Dohse (2000, p. 1111) pointed out that the implementation of regionalized technology policy in Germany was not purely intended to be a "...carbon-copy of the ideas proposed in the theoretical literature".
} 
inventors. Likewise, Baptista and Swann (1998), based on UK micro data, show that firms in sectors that show a geographical concentration indeed exhibit, on average, more intensive research activities. In a further study, Baptista (2000) shows that firms adopt technical innovations particularly in those regions which are characterized by a high share of firms having implemented the same innovations already. With respect to Germany, Dauth (2010), among others, finds empirical evidence that the existence of industrial agglomerations is significantly correlated with higher regional employment growth rates, compared to regions which are not clustered.

The main question remains how to interpret such findings. For example, Baptista (2000, p. 529) states: "...[o]ne can, therefore, claim that there are significant learning effects arising from the geographical proximity to previous adopters". In fact, it is quite probable that learning effects are higher in local agglomerations due to the existence of firms with higher knowledge competencies and absorptive capacities. One may then assume that local agglomerations are characterized by a "selection of the fittest", that is, actors with research activities and knowledge competencies above average prefer geographical proximity to actors with similar skills. Studies by Zucker et al. (2006) and Klepper (2007) clearly support this view. Klepper (2007), for instance, argues that betterperforming firms will have more and better spinoffs, and these spinoffs will generally locate close to their parents. Zucker et al. (2006) are able to show that scientific stars become more geographically concentrated over time because of relocations from areas with relatively few peers to those with many actors in their field of expertise. If selection of the fittest works, then geographical proximity between well-performing actors might indeed be useful for knowledge transfer. However, so far empirical research has not tackled this puzzle clearly.

To sum up, higher economic outcomes of local agglomerations based on the selection of the fittest, geographical proximity, and the interplay between both driving forces seem to matter for $R \& D$ activities. These insights are essential for understanding any potential effect stemming from a regionalized, cluster-oriented R\&D policy. The funding of projects in such leading-edge local agglomerations might have larger outcomes due to the acquisition of outside money, and higher effectiveness based on the selection of the fittest and the geographical proximity between well-performing actors.

\subsection{Cluster-oriented R\&D policy and its evaluation}

The BioRegio contest (BRC) marks a major milestone of the German Federal Government's policy to stimulate the transfer of new knowledge into new products and thereby narrow the gap between Germany and those countries leading in the application of biotech- 
nological knowledge, i.e. the USA and Great Britain. The BRC was initiated by the Federal Ministry of Education and Research (BMBF) in 1995 and encouraged regions to apply for subsidies to be used in establishing a biotech industry in the region (Dohse 2000). The funding concept aimed at developing a new holistic approach for R\&D and innovation policy and was planned to integrate biotechnological capacities and scientific, economic and administrative activities. The governmental purpose of funding biotechnology was - and still is - for the German field of life sciences to catch up with the high international standard of performance. From the political perspective there should be a direct $R \& D$ and output enhancing effect of the exclusive funding for winning regions as well as additionally a reputation effect. Moreover, further indirect effects may be expected from the approach. These can potentially arise for non-winning participants due to a mobilization effect of the contest, that is, regions which have organized themselves and formulated a common strategy can use these efforts as a future asset even without receiving financial benefits. Indirect effects thus mean to push developing strategies and financial backing at all locations in Germany with a critical mass in biotech research.

In sum, 17 BioRegions were formed and participated in the BRC. An independent jury selected four winning regions (Rhineland, Rhine-Neckar, Munich, and Jena with special vote) out of a total of 17 participant "meso"-regions (clearly exceeding the size of NUTS-3 districts). Major criteria were based on "hard" facts like the existence of a critical mass of biotech firms and research facilities within the region, regarding the absolute number of firms, the average firm size, and the firms' R\&D and economic performance (for details, see Dohse, 2000). Each winning region received a total amount of public grants of about 25 Mio. (exception Jena: 15 Mio.) to conduct R\&D-projects. Additionally, winning regions were favoured in terms of getting access to the standard R\&D-grant schemes of the BMBF. The total amount of these grants was about 750 Mio. for the time span 1997-2001. The follow-up BioProfile contest (BPC) started in 1999, and a total of 30 regions participated in this contest. Three winner "clusters" (Potsdam/Berlin, Braunschweig/Goettingen/Hannover, Stuttgart/Tuebingen/Esslingen/Reutlingen/Neckar-Alb) have been awarded funding by the jury in May 2001. Public subsidies amounting to 50 Mio. were provided by the Federal Government for the three clusters for the period 2001 to 2007.

Participation in the BRC and BPC was thus attractive in order to receive additional subsidies and to attract actors within the region and outside the region for participation in biotech-related research projects. It also offered access to different valuable resources which could give rise to increasing knowledge competencies, accelerating the commercialization of biotechnology-related products. 
Despite its growing political importance, there are only very few quantitative studies that aim to measure the success of cluster-oriented R\&D policies. Looking at the international evidence, Martin et al. (2010) were among the first scholars to apply a quantitative (DiD) approach to the evaluation of economic effects of the French "Local Productivity System" (LPS) cluster programme. A further analysis for the subsequent French Policy of "Competitiveness Clusters" has been conducted by Fontagne et al. (2010), mainly finding that the policy was effective in picking the winners. With respect to German data, Falck et al. (2010) use a similar estimation strategy in order to analyse a regional innovative cluster policy for Bavaria. While Martin et al. (2010) do not find evidence of productivity advantages of the specific cluster policy; Falck et al. (2010) conclude that the Bavarian state-wide cluster policy led to a significant increase in the probability of being innovative for Bavarian targeted sector relative to non-Bavarian targeted sectors and Bavarian non-targeted sectors (two comparison groups). In fact, the Bavarian State Government provided an amount of 1.45 billion for $R \& D$ projects to Bavarian firms and research institutes, which comes close to typical funding schemes at the Federal government level.

While several earlier papers (e.g., Czarnitzki et al. 2007) already pointed out that R\&D funding positively affects R\&D activities of the grant recipients, the findings of Falck et al. (2010) are clearly in line with this strand of literature and additionally add further insights with respect to the role of financial support explicitly designed to support the research effort of innovative clusters. From the viewpoint of public authorities, it is desirable to know whether cluster-oriented funding schemes imply greater outcomes compared to individual funding, and to know how clusters perform after the funding period.

Specific to the biotechnology sector, different studies have both analysed the role of clustering as well as public funding. Using a global dataset for 59 consolidated biotechnological firms, Lecocq et al. (2009) find significant evidence that there is a positive relationship between the number of technology clusters, in which a firm is present, and its overall technological performance measured by the number of patents. Similar results are also reported in Fornahl et al. (2009) for a sample of German biotech firms in the period 1997-2004. Wolf et al. (2010) analyse the determinants of transition from nascent into real entrepreneurship for German biotechnology firms. The authors confirm the role of regional factors and the entrepreneurial environment, which are both specific in clusters, for the success in the start-up activity of biotechnology firms.

Looking at policy effects, recently Cooke et al. (2007) compared several measures for the success of policy support in the biotechnology sector (e.g., number of biotech firms, products in pipeline). The authors find that BRC as well as BPC winners perform better 
than non-funded biotech regions. However, the authors do not differentiate between non-winning participants and non-participants within the group of non-funded biotech regions. In doing so, Engel and Heneric (2008) find that non-winning participants of BRC outperform winning and non-participants regions of $\mathrm{BRC}$ with respect to the change in the number of newly founded biotech-firms between 1995-1998 and 1999-2003. Thus, the authors conclude that the certification as winner and exclusive financial support do not matter in attracting new biotech firms, compared to other participants.

A shortcoming of both studies is that the authors do not address the evolution of BRC winning regions after the funding period. Using actual data for the total amount of public R\&D funds raised, we take up this research question explicitly. While many studies point out that public funding implies higher R\&D activity of firms, we are explicitly interested to know whether path dependence matters for the acquisition of $R \& D$ funding. Furthermore, we will provide empirical evidence on whether BRC and BPC winning regions were more successful in terms of patent applications during the funding period.

\section{Data and empirical estimation strategy}

\subsection{Data and variable definition}

In the following, we give a short description of the variables employed to analyse the effects of the BRC and BPC at the level of the 426 German NUTS-3 districts. Several databases are needed to analyse the regional structure of Federal support for biotechnology projects and its determinants. In detail, we link the following data sources (see table 1):

- Federal Government Project Funding Information Database (PROFI),

- Patent data from the European Patent Office (EPO), namely "ESPACE" Bulletin,

- Socio-Economic data from various sources including Federal Agency for Labour, ZEW Foundation Panel, as well as the Federal Statistical Office.

The PROFI database covers the civilian R\&D funding of the German Federal Government. For the purpose of this paper, we focus on direct funding of biotechnology-related projects. The database contains information on the number of projects, expenditures, name and address of recipients, type of project (individual versus collaborative projects), and so on. ${ }^{3}$ Based on the "ESPACE" Bulletin, we extract information regarding patenting

\footnotetext{
${ }^{3}$ We thank Mr. Günter Krauss from the Federal Ministry of Education and Research - Department Z 22 'Information technology' for his effort to extract related information from the PROFI database. In order to minimize the potential endogeneity problem stemming from the fact that winning the contests is directly associated with financial benefits for
} 
behavior. Patent applications are the most important measure of innovative capacity (see e.g. Griliches, 1990, for comprehensive discussions on the informative value of patents). We measure patent applications in the technology field "biotechnology" at the location of inventors, and add up the number of patent application per county when at least one inventor comes from this county.

Acquisition of public funding and patent applications as outcome variables are determined by the innovative capacity in the region. In order to minimize any bias stemming from time-varying omitted variables, our set of explanatory variables thus considers, within the set of regressors, several aspects of the districts' innovative capacity, which are extracted from several databases. Among others, R\&D employment data, defined as the share of employees trained in mathematics, engineering and natural sciences relative to total employment, and obtained from the Federal Employment Agency, are used to extract measures regarding the innovative capacity of counties. We add further research activity specific measures like firm-specific information in the manufacturing sector (export share, firm size etc.) and start-up activity in high-tech industries. The latter critical variable measures the entrepreneurial climate and thus, the potential to commercialize innovative ideas via the channel of creating a new business. Finally, we also include measures for the regional patterns in sectoral specialization and agglomeration in general. The latter variable is proxied by employment in sectors with a high Ellison-Glaeser-Index (>0.005) relative to total employment in the region. ${ }^{4}$ This measure, in turn, may provide general information about the Marshallian forces at work at the NUTS-3 level (that is, forward-backward linkages, labour market pooling and knowledge spillovers). A detailed description of the data definitions is given in Table 1.

For the empirical analysis we collapse the yearly observations from our sample data into three periods: 1.) Pre-treatment period, 2.) treatment period and 3.) post-treatment period. The time span of each period differs for BRC and BPC due to the fact that $\mathrm{BPC}$ ran two years after BRC (see Table 2). Therefore we prepare two samples, one for the evaluation of $\mathrm{BRC}$ and the other one for the evaluation of BPC. The first BRC sample contains BRC winners, non-winning participants and non-participants. ${ }^{5}$ While non-winning participants are needed as comparison group to assess the likely direct effects

\footnotetext{
the respective regions; we use the number of raised research projects rather than the financial volume. The correlation of both indicators is reasonably high (Pearson's correlation coefficient is 0.87 for all projects and 0.91 for cooperative R\&D projects), so that the number of projects serve as a good substitute for the financial volume. This strategy also avoids to put strong assumptions on the annual streams of funding over the project period.

${ }^{4}$ The threshold level of $>0.005$ was chosen in line with the empirical literature, see, e.g., Alecke et al. (2006).

${ }^{5}$ Although the BioRegio contest was officially set up on a five year basis, between 1997 and 2001, we include an additional year as treatment period in order to account for the usual funding practice according to an $\mathrm{N}+1$ period, where $\mathrm{N}$ stands for the nominal time span of a specific policy programme.
} 
Table 1: Variable description and data source

\begin{tabular}{|c|c|c|}
\hline Variable & Source & Description \\
\hline $\begin{array}{l}\text { Government } \\
\text { funding }\end{array}$ & PROFI database & $\begin{array}{l}\text { Direct funding of biotechnology } \\
\text { related R\&D projects by Federal } \\
\text { government (number of projects and } \\
\text { volume of expenditures) }\end{array}$ \\
\hline Patents & $\begin{array}{l}\text { European Patent Office } \\
\text { (EPO) }\end{array}$ & $\begin{array}{l}\text { Non-weighted number of patent } \\
\text { application in biotechnology (for a } \\
\text { definition of the Biotech sector based } \\
\text { on IPC classes see appendix) }\end{array}$ \\
\hline Number of Firms & German Statistical Office & $\begin{array}{l}\text { Number of firms in manufacturing } \\
\text { sector }\end{array}$ \\
\hline Average Firm size & German Statistical Office & $\begin{array}{l}\text { Average number of employees per firm } \\
\text { in manufacturing sector }\end{array}$ \\
\hline Export share & German Statistical Office & $\begin{array}{l}\text { Share of foreign turnover in } \\
\text { manufacturing sector relative to total } \\
\text { turnover in manufacturing sector }\end{array}$ \\
\hline R\&D Employment & $\begin{array}{l}\text { Bundesagentur für Arbeit } \\
\text { (Federal Employment } \\
\text { Agency) }\end{array}$ & $\begin{array}{l}\text { Share of employees trained in } \\
\text { mathematics, engineering and natural } \\
\text { sciences relative to total employment }\end{array}$ \\
\hline Start-up & ZEW Foundation Panel & $\begin{array}{l}\text { Number of overall start-ups relative to } \\
\text { total employment }\end{array}$ \\
\hline $\begin{array}{l}\text { Start-up } \\
\text { (High-Tech) }\end{array}$ & ZEW Foundation Panel & $\begin{array}{l}\text { Number of start-ups in high-tech } \\
\text { industries relative to R\&D employees }\end{array}$ \\
\hline Population Density & German Statistical Office & Number of inhabitants per sqm. \\
\hline $\begin{array}{l}\text { Sectoral } \\
\text { Specialization }\end{array}$ & Alecke et al. $(2001,2006)$ & $\begin{array}{l}\text { Sum of squared deviations in } \\
\text { employment shares for NACE3 sectors } \\
\text { between regional and national average }\end{array}$ \\
\hline $\begin{array}{l}\text { Ellison-Glaeser } \\
\text { Index }\end{array}$ & Alecke et al. $(2001,2006)$ & $\begin{array}{l}\text { Employment in sectors with high } \\
\text { Ellison-Glaeser-Index }(>0.005) \\
\text { relative to total employment in the } \\
\text { region }\end{array}$ \\
\hline Dummy BioProfile & Cooke et al. (2007) & $\begin{array}{l}\text { Binary dummy for winner districts in } \\
\text { the BioProfile contest (complete list } \\
\text { see appendix) }\end{array}$ \\
\hline $\begin{array}{l}\text { Dummy BioRegio } \\
\text { Winner }\end{array}$ & Dohse (2000) & $\begin{array}{l}\text { Binary dummy for winner districts in } \\
\text { the BioRegio contest (complete list see } \\
\text { appendix) }\end{array}$ \\
\hline $\begin{array}{l}\text { Dummy BioRegio } \\
\text { Participant }\end{array}$ & Dohse (2000) & $\begin{array}{l}\text { Binary dummy for non-winning } \\
\text { districts in the BioRegio contest } \\
\text { (complete list see appendix) }\end{array}$ \\
\hline
\end{tabular}


of funding, non-participating regions serve as second comparison group (both relative to winners and non-winners) in order to give a first quantification of the possible indirect effects of funding as outlined above. We exclude BPC winners from the group of nonwinning participants in this sample since BPC winners partly also received funding during the BRC. This exclusion might be critical given that the BPC winners are an ideal control group for BRC winners since we do not face the problem of self-selection into the treatment here. Both groups only differ with respect to the timing of exclusive funding and the label "winner". Therefore, we prepare a second BRC subsample (labeled BRC2) to improve the similarity between the treatment and the comparison group. This approach has the disadvantage of shortening the investigation period. While many R\&D projects started immediately after the announcement of "BRC winner" we believe that losing two years does not fundamentally affect the precision of our estimates. Descriptive statistics of the samples according to Table 2 are given in the Appendix.

Table 2: Samples under investigation

\begin{tabular}{lllll}
\hline \hline & $\begin{array}{l}\text { Outcome } \\
\text { variable }\end{array}$ & $\begin{array}{l}\text { Pre-treatment } \\
\text { period (before } \\
\text { funding) }\end{array}$ & $\begin{array}{l}\text { Treatment } \\
\text { period (exclusive } \\
\text { funding) }\end{array}$ & $\begin{array}{l}\text { Post-treatment } \\
\text { period (after } \\
\text { funding) }\end{array}$ \\
\hline BRC1 $^{a}$ & Funding & $1991-1996$ & $1997-2002$ & $2003-2007$ \\
& Patents & $1991-1997$ & $1998-2006$ & n.a. \\
$\mathrm{BRC}^{b}$ & Funding & $1991-1996$ & $1997-2000$ & n.a. \\
& Patents & $1991-1997$ & $1998-2002$ & n.a. \\
$\mathrm{BPC}^{c}$ & Funding & $1991-2000$ & $2001-2007$ & n.a. \\
& Patents & $1991-2000$ & $2002-2006^{d}$ & n.a. \\
\hline \hline
\end{tabular}

Notes: We assume that patent applications based on funding are earliest declared one year after the beginning of exclusive funding and latest one year after the exclusive funding is closed. Example: While funded RD projects in BRC winners have to be finished until 2005, patent applications based on exclusive funding are declared until 2006.

$a$ : The sample contains BRC winners, non-winning BRC participants (without BPC winners) and non-participants.

$b$ : In addition to sample BRC1 the sample BRC2 contains BPC winners.

c: The sample contains BPC winners, non-winning BRC participants and non-participants of BRC.

$d$ : Due to limitations in patent data we can only consider five years instead of seven years in the ideal case.

Although collapsing the yearly observations into three time periods results in a loss of information, there are also statistical reasons that advocate carrying out the DiD estimation strategy this way. Bertrand et al. (2004), for instance, propose to collapse data with a long sample range into just two periods (one before and one after the policy intervention) in order to minimize the risk of obtaining underestimated standard errors due to serially correlated errors when unobservable factors are present over time. Since knowledge production in biotechnology is a complex issue (i.e., is difficult to model adequately), correlation of errors can be expected over cross-sections, which makes collapsing the dataset into three periods a reasonable empirical estimation strategy. Additionally, 
certain variables such as start-up activity are only available at longer time intervals, so that the decision of collapsing the data is also a practical issue. For the outcome variables, we sum up the number of patents and publicly funded projects observed for each region for the time intervals defined in Table 2. For the set of explanatory variables, we use sample averages for each respective time period.

Table 3 shows that both the number of directly funded projects and the sum of allocated grants in the field of biotechnology increased significantly between 1991 and 2007. In particular, we observe a take-off in the figures between the periods 1991-1996 and 19972002, which may give a first indication of the boost in Biotech funds throughout the BRC competition. Compared to this, for the period 2003-2007 we observe a consolidation phase of public R\&D spendings to biotechnology. The apparent time trend faced by the whole industry makes it thus important not only to compare the performance of winner regions over time but also relative to the other actors in order not to erroneously allot the positive industry trend to the causal impact of BRC (and BPC) funding.

Table 3: Directly funded biotechnology related R\&D projects by the German Federal Government

\begin{tabular}{llll}
\hline \hline & $\begin{array}{l}\text { Pre-treatment } \\
\mathbf{1 9 9 1 - 1 9 9 6}\end{array}$ & $\begin{array}{l}\text { Treatment } \\
\mathbf{1 9 9 7 - 2 0 0 2}\end{array}$ & $\begin{array}{l}\text { Post-treatment } \\
\mathbf{2 0 0 3 - 2 0 0 7}\end{array}$ \\
\hline $\begin{array}{l}\text { Number of directly funded } \\
\text { projects }\end{array}$ & 3,692 & 4,482 & 4,603 \\
$\begin{array}{l}\text { Total amounts of directly } \\
\text { funded projects (in } € 1000)\end{array}$ & 723,995 & $1,055,159$ & $1,331,133$ \\
\hline \hline
\end{tabular}

Table 4 and Table 5 show the allocation of federal funds with respect to the different regions, and the share of cooperative $R \& D$ projects, respectively. Table 4 points out that BRC winners could increase their relative share of allocated fund during the treatment period 1997 to 2002 even further. However, for the post-treatment period, we see a significant bump in the regional share of total direct project funds. On the contrary, nonwinning BRC participants were able to significantly increase their share. The same applies for BPC winners and other (non-participating) NUTS-3 districts. Moreover, BRC winners face a relative reduction in their share for the post-treatment period, which turns out to be lower compared to their pre-treatment share. This observation may give rise to the hypothesis that the exclusive funding follows the rationales of time-limited commitments to push the evolution of regions further. Finally, the table shows that, in absolute terms, the different treatment and comparison groups appear to have received a fairly similar share of funding indicating that they may serve as homogeneous comparison groups with respect to the outcome variable of publicly funded $R \& D$ projects. 
Table 4: Allocation of federal direct project funding to biotechnology programs; percentage shares

\begin{tabular}{llll}
\hline \hline Participation State & $\begin{array}{l}\text { Pre-treatment } \\
\mathbf{1 9 9 1 - 1 9 9 6}\end{array}$ & $\begin{array}{l}\text { Treatment } \\
\mathbf{1 9 9 7 - 2 0 0 2}\end{array}$ & $\begin{array}{l}\text { Post-treatment } \\
\mathbf{2 0 0 3 - 2 0 0 7}\end{array}$ \\
\hline BRC winner & 32.1 & 33.8 & 27.3 \\
Non winning BRC & 17.1 & 15.0 & 18.6 \\
participants & & & \\
BPC winner & 24.1 & 24.5 & 26.6 \\
Other NUTS-3 districts & 26.6 & 26.7 & 27.5 \\
Sum (Germany) & 100.0 & 100.0 & 100.0 \\
\hline \hline
\end{tabular}

Finally, Table 5 further highlights that, for all regions, the share of cooperative R\&D projects increased over time. It seems that exclusive funding for "winners" correlates with the extension of collaborative projects. BRC and BPC winners show a significant increase in the share of collaborative projects during the treatment period (1997-2002 for BRC and 2001-2007 for BPC). Most interesting, the importance of collaborative projects (as share of overall projects) reduces for BRC winners in the post-treatment period.

Table 5: Percentage share of cooperative R\&D projects relative to overall funding per group

\begin{tabular}{llll}
\hline \hline Participation State & $\begin{array}{l}\text { Pre-treatment } \\
\mathbf{1 9 9 1 - 1 9 9 6}\end{array}$ & $\begin{array}{l}\text { Treatment } \\
\mathbf{1 9 9 7 - 2 0 0 2}\end{array}$ & $\begin{array}{l}\text { Post-treatment } \\
\mathbf{2 0 0 3 - 2 0 0 7}\end{array}$ \\
\hline BRC winner & 20.4 & 36.9 & 29.0 \\
BPC winner & 32.3 & 42.9 & 49.6 \\
Non winning BRC & 31.6 & 39.0 & 40.3 \\
participants & & & \\
Other NUTS-3 districts & 26.4 & 42.9 & 42.9 \\
\hline \hline
\end{tabular}

Given the fact that patenting activity inherently exhibits a time lag in the transmission process from $R \& D$ funds to $R \& D$ activity and finally $R \& D$ outcome, in this paper we are only able to compare the treatment effect relative to the pre-treatment period for winning regions of the BRC/BPC with the specific comparison groups. Due to restrictions in patent data publication, as well as time lags in the transmission from R\&D inputs to outputs, we cannot construct a sufficiently long post-treatment period. Thus, for patent applications, we set the treatment and pre-treatment periods as follows: from 1991 to 1997, we assume that there is -by definition- no significant patent application activity as a result of the BRC. Instead, for the period 1998 to 2006, we assume that patent applications are directly influenced by the BRC (2002-2006 for the BPC). As Table 6 shows, BRC winning regions significantly increased their number of patents in the treatment period. The growth rate was about $+183 \%$. However, also BPC winners showed a significant boost in their patenting activity $(+281 \%)$, showing the strongest growth performance 
among all four groups. Compared to BRC winners Table 6 shows that BPC winners were initially smaller in absolute size, but showed a convergence to the BRC level throughout the sample period. For the non-winning participants, as well as for all remaining NUTS3 districts, the number of patent applications showed a smaller increase $(+93 \%$ and $+168 \%$, respectively). Finally, compared to public R\&D spendings from Table 6, we also see that here the inter-group heterogeneity is much higher, indicating that especially the comparison between winning and participant regions is expected to yield the utmost reliable results in the estimation approach trying to minimizing any possible self-selection bias. We turn to the model setup in the following.

Table 6: Total number of biotech patent applications (Average per NUTS-3 district for each category)

\begin{tabular}{llll}
\hline \hline & $\begin{array}{l}\text { Pre-treatment } \\
\mathbf{1 9 9 1 - 1 9 9 7}\end{array}$ & $\begin{array}{l}\text { Treatment } \\
\mathbf{1 9 9 8 - 2 0 0 6}\end{array}$ & Growth rate \\
\hline BRC winner & 83.6 & 236.6 & $+183.0 \%$ \\
non winning BRC participants & 49.2 & 95.1 & $+93.3 \%$ \\
(excluding BPC winner) & & & \\
BPC winner & 55.7 & 212.3 & $+281.1 \%$ \\
Other NUTS-3 districts & 9.2 & 24.7 & $+168.4 \%$ \\
\hline \hline
\end{tabular}

\section{Econometric approach and estimation results}

\subsection{Model setup}

As outlined above, in order to carefully analyse the effects of funding on private $R \& D$ activity, we have to estimate a set of models which differs by the design of the treatment versus the comparison group and the time period employed, as shown in Table 2. The econometric literature offers different approaches how to estimate treatment effects. Here we apply a Difference-in-Difference (DiD) techniques, which aims at isolating the policy related effect related to changes in the outcome variable $Y_{i, t}$ for a group of treated individuals ( $i$, in our case: NUTS-3 regions) over time $(t$, in our case: limited to two consequtive periods) relative to a comparison group. The underlying assumption of this approach is that the difference between the treatment and comparison groups would have been constant over time if the treatment group had not received the subsidy. Since we are dealing with three groups (winners, participants and non-participants), our model specification has the following general form 


$$
Y_{i, t}=\alpha+\beta_{1} D_{i}^{1}+\beta_{2} D_{i}^{2}+\gamma T_{t}+\delta_{1}\left(D_{i}^{1} \times T_{t}\right)+\delta_{2}\left(D_{i}^{2} \times T_{t}\right)+\omega^{\prime} \mathbf{X}_{i, t}+u_{i, t},
$$

where $D_{i}^{1}$ and $D_{i}^{2}$ are defined as binary dummy variables with values

$$
\begin{aligned}
& D_{i}^{1}=\left\{\begin{array}{l}
1 \text { if region } i \text { belongs to the group of contest winners, } \\
0 \text { otherwise; }
\end{array}\right. \\
& D_{i}^{2}=\left\{\begin{array}{l}
1 \text { if region } i \text { belongs to the group of non-winning participants, } \\
0 \text { otherwise. }
\end{array}\right.
\end{aligned}
$$

Thus, the third group of non-participating regions serve as the benchmark case, for which we do not include a separate dummy variable in the regression equation. Statistically significant positive parameters for $D_{i}^{1}$ and $D_{i}^{2}$ indicate that both winners and non-winners show a significant level effect regarding the outcome variable. Besides these dummy variables, we also include a common time trend $T$, which takes either a value of zero (pre-treatment period) or one (treatment or post-treatment period respectively), but does not change in the cross-sectional dimension $i$. The crucial parameters of interest are the two DiD terms, which are calculated as interaction effect between the common time trend and the individual group dummies as $\left(D_{i}^{1} \times T_{i}\right)$ and $\left(D_{i}^{2} \times T_{t}\right)$ and thus measure the difference between the expected outcome for treated regions before and after the treatment is thus diminished by the outcome difference of the comparison group during the treatment.

Statistically significant parameters $\delta_{1}$ and $\delta_{2}$ indicate a positive treatment effect for each subgroup relative to the benchmark case of non-participant regions. ${ }^{6}$ They can be interpreted as the combined direct and indirect effects of funding, respectively. By testing for parameter restrictions in terms of $\delta_{3}=\left(\delta_{1}-\delta_{2}\right)$, we are finally able to identify the treatment effect of winners versus non-winners within only single regression exercise, which allows us to isolate the direct treatment effect of funding. In other words, the latter can be defined as a difference in the difference-in-difference (DiDiD) parameter. As argued above, we are especially interested in this parameter since the risk of inducing a self-selection bias is smaller for this comparison setup.

This model setup has the advantage that it does not lose its validity in case of time-

\footnotetext{
${ }^{6}$ Specifically, $\delta$ with measures the change in expected outcome variable $E(Y)$ for treated $(D=1)$ and non-treated individuals $(D=0)$ between the treatment $(t=1)$ and pre-treatment $(t=0)$ periods as$$
\delta=(E[Y \mid D=1, t=1]-E[Y \mid D=1, t=0])-(E[Y \mid D=0, t=1]-E[Y \mid D=0, t=0]) .
$$ 
invariant omitted variables. However, it is sensitive to temporary fluctuations that may influence the performance of the treatment and control groups differently. The latter problem can be handled by including a set of time-varying control variables $(\mathbf{X})$ for further regional characteristics, like the number of firms, new firm formations, the international competiveness, share of R\&D employees, sectoral specialization and agglomeration. $u_{i, t}$ is the error term of the model and $\alpha, \beta_{1}, \beta_{2}, \gamma$ and $\omega$ are further regression coefficients.

Since we are dealing with patent and $R \& D$ grants count data that exhibits a high share of zeros, the underlying distribution of the outcome variables may be non-normal distributed, nor conforming to a regular or overdispersed Poisson. A common solution to this problem is to rely on a so-called zero-inflated Poisson (ZIP) model, which assumes different data generating processes are in order to predict the general probability of regional R\&D activity in terms of a binary choice model (Probit or Logit specification) and its actual (non-zero) size estimated by means of standard Poisson model. For our estimation approach, we explicitly test for the appropriateness of the ZIP specification versus the standard Poisson model by means of standard postestimation tests.

Moreover, a crucial point for our empirical policy analysis is whether the estimated DiD parameters in the (non-linear) ZIP model can be interpreted in the usual (linear) fashion. For the case of the Poisson model, the answer is straightforward, since the latter is just a flexible generalization of the ordinary least squares regression. In other words, we are still in the linear case and the usual assumptions hold. Since the Poisson model uses the logarithm as the link function, we can obtain the marginal effect for the DiD parameter as $[\exp (\delta)-1]$.

In contrast to this, Ai and Norton (2003) have recently argued that, if the DiD term is included in the non-linear Probit/Logit part of the model, interaction terms have to be analysed with caution, since both the reported significance and their qualitative interpretation may be misleading. On the other hand, Puhani (2008) has shown that the DiD interaction term in non-linear models can still be interpreted in the same way as the linear case, as long as the model has a strictly monotonic transformation function. ${ }^{7}$ This latter condition holds both for the Probit as well as the Logit specification. Irrespectively of this debate, for the research question at hand, it turns up to be more convenient including the DiD term only in the Poisson part rather than the non-linear Probit/Logit specification. This decision can be motivated by the argument already given above that both the BRC and BPC aim to improve the track record of promising biotech regions rather than initiating a regime switch from non-innovators to innovators.

\footnotetext{
${ }^{7}$ In this case, the consideration of cross differences is not relevant for the estimation of treatment effect models, as far as the non-linear specification is a strictly monotonic transformation function of the linear model.
} 


\subsection{Estimation results}

In this section we estimate different ZIP models for the samples designed according to table 2. Statistical inference for the two DiD terms is made directly from the regression output, significance of the DiDiD term is tested ex-post based on the so-called delta method (for details, see Greene 2003). As argued above, while the comparison of participants in a broad sense (that is, both winning and non-winning regions) relative to other NUTS-3 districts serves as a first indicator for policy effectiveness, the comparison of programme winners relative to non-winning but participating regions allows in particular to answer the question of whether the proclamation of the contests itself was a signal strong enough to encourage R\&D networks, or whether actual extra funding was necessary in order to boost $R \& D$ activity in the short and medium run. In all empirical specifications, we include a broad set of regional control variables $(\mathbf{X})$, as listed in Table 1 . The main empirical results regarding the parameter of the DiD term for different sample designs are given in Table 8. Full regression outputs are reported in Table 8 to Table 9.

Table 7: Estimated elasticity for the DiD interaction term according to different subsamples of the data

\begin{tabular}{lccc}
\hline \hline Elasticity of DiD term & Patents & $\begin{array}{c}\text { R\&D Projects } \\
\text { total }\end{array}$ & $\begin{array}{c}\text { R\&D Projects } \\
\text { collaborative }\end{array}$ \\
\hline Panel A.1: Treatment Period for BRC1: Period 2 versus Period 1 & \\
\hline Winner / Non-Winner & $0.72^{* * *}$ & $0.37^{* * *}$ & $0.41^{* * *}$ \\
Winner / Others & $0.59^{* * *}$ & $0.43^{* * *}$ & $0.49^{* * *}$ \\
Non-Winner / Others & $-0.07^{* *}$ & 0.04 & 0.06 \\
\hline Panel A.2: Treatment Period for BRC2: Period 2 versus Period 1 & $0.55^{* * *}$ \\
\hline Winner / Non-Winner (All) & $0.15^{* * *}$ & $0.46^{* * *}$ & $0.61^{* * *}$ \\
Winner / Non-Winner (Only BPC) & $-0.28^{* * *}$ & $0.52^{* * *}$ & $0.49^{* * *}$ \\
Winner / Non-Winner (Rest) & $0.61^{* * *}$ & $0.41^{* * *}$ & 0.09 \\
\hline Panel B: Post Treatment Period for BRC1: Period $\mathbf{3}$ versus Period 1 & $0.25^{* *}$ \\
\hline Winner / Non-Winner & n.a. & $0.24^{* * *}$ & 0.14 \\
Winner / Others & n.a. & 0.09 & \\
Non-Winner / Others & n.a. & $-0.11^{*}$ & $0.36^{* * *}$ \\
\hline Panel C: Treatment Period for BPC: Period 2 versus Period 1 & $0.38^{* * *}$ \\
\hline Winner / Non-Winner & $0.42^{* * *}$ & $0.32^{* * *}$ & 0.02 \\
Winner / Others & -0.04 & $0.07^{*}$ & $-0.18^{* * *}$ \\
Non-Winner / Others & $-0.33^{* * *}$ & & \\
\hline \hline
\end{tabular}

Notes: ***,**** indicate statistical significance at the 1, 5 and $10 \%$ level. The reported elasticities are calculated as $[\exp ($ coef $)-1]$, where coef is based on the DiD and DiDiD parameters of the full regression outputs given in Tables $8-11$. 
As Panel A.1 in Table 7 (for the BRC) shows, we detect a positive and statistically significant higher number of patent application and raised R\&D projects for BRC winners compared to non-participants throughout the treatment period. Likewise, the result holds for all $R \& D$ projects, as well as for the sub-group of collaborative $R \& D$ projects. These findings clearly support the existence of direct treatment effects of funding, and suggest that the label "winner" signals an above-average R\&D performance as well as may contribute positively to a better innovative performance in biotechnology. However, we do not find evidence of indirect effects of funding when analysing the estimated DiD term parameters in Panel A.1. That is, we do not find any statistically significant effect with respect to publicly funded $R \& D$ project allocation when comparing the performance of non-winning regions with the non-participating comparison group. For patents Table 7 even reports negative results.

The drawback to the approach in Panel A.1 is that one may still argue that BRC winners differ from remaining regions with respect to adjustments due to environmental changes. $^{8}$ The implementation, in April 1997, of the "Neuer Markt", Germany's equivalent to the United States' NASDAQ, and its rapid growth measured by the number of listed companies and market capitalization, marks a remarkable change. While highly profitable exit opportunities are offered to investors in non-listed firms, venture capital investments in biotechnology went up by a factor of six between 1997 and 2001 (see OECD 2006: 119). According to the "selection of the fittest"-hypothesis, firms and scientists in BRC winning regions are more stimulated by the rapid growth of the venture capital market. As a result, inventions could be better protected by patent applications to secure a unique selling proposition in the commercialization process of innovative ideas. However, comparing $\mathrm{BRC}$ winners with BPC winners (as a comparison group in BRC2) may be seen as an effective strategy to eliminate some of above-mentioned differences in adjustments to temporary shocks. In detail, the share of venture capital-financed firms does not differ remarkably between BRC and BPC winners (see Engel and Heneric 2005).

To account for these structural differences, in Panel A.2 we report the estimation results of the BRC2 sample, where we compare the relative performance of $\mathrm{BRC}$ winners against the one of non-winning participants, including BPC winners, prior to the starting date of the latter competition. The results for patent applications show that BRC winners again show a better track record compared to the remaining full candidate set for the treatment period (1998 - 2002), both in terms of patent applications and of the number

\footnotetext{
${ }^{8}$ Additionally, we have to keep in mind that the group of non-winning participants is defined as net of the winning regions from the $\mathrm{BPC}$ contest, and thus has been subject to a dual selection mechanism, leaving within this group only poor candidates
} 
of raised R\&D projects. However, if we split the latter candidate set into BPC winners and remaining participants, we see that the obtained positive direct treatment effect of BRC winners for patent applications stems mainly for the relative track record of winners relative to non-winners (net of BPC winners). Compared to them, BPC winners show a better patent performance, while they clearly fall behind in terms of raising R\&D funds.

Given the absence of direct effects (or even negative ones) for patent activity between $\mathrm{BRC}$ and BPC winners, one may thus raise the question of whether the selection mechanism in the BRC competition was operating poorly. However, in order to answer such question, one has recall that the goal of the programme was to push the technological competitiveness of German biotechnology towards an international dimension. As the regression parameters for the dummy variables in Table 8 show, the level of BRC winners was more than twice as large as the reference group, while BPC winners were only 1.2 times larger in terms of patent applications. Thus, among the positively performing candidates, the jury clearly picked the heavyweights, compared to the dynamically growing - but smaller - 'rising stars'. The latter were actually selected in the second stage, the BPC. This finding provides further empirical evidence that both the BRC and BPC are a sequential result of "picking the winners" as argued, for example, by Dohse (2000).

In search of long-term effects of BRC participation and exclusive funding, we present, in Panel B, findings for the R\&D performance of BRC winners and the comparison groups in the post-treatment period. This comparison may give an indication of which new equilibrium levels will be reached after the extensive funding by the BRC. On the one hand, we may expect that receiving additional public funding allows competence building, and thus, positive path dependence should matter. On the other hand, the number of raised public R\&D grants may actually follow different motives than allocating $R \& D$ facilities to the most successful region (e.g., distributive rather than allocative arguments from a policy perspective). As the results in Table 7 show, in comparison with the shortterm effects in the treatment period, statistical evidence for long-term effects of funding is indeed much weaker. Although BRC winners still tend to outperform non-winners with respect to raised public $R \& D$ funds, there is no evidence of an overall better performance compared to non-participating regions, and non-winners even appear to fall behind the reference group of non-participating regions.

Compared to non-participating regions, the only significant difference of BRC winners is their ability to raise more collaborative projects. This result hints at the successful network creation resulting from the funding period. We do not find statistically significant long-term effects comparing non-winning participants and other regions. This latter result may point to the fact that the number of biotech regions has grown over time and, likewise, 
to their attempts to increase the propensity their success rate in the acquisition of $R \& D$ grants. BRC non-winners and non-participants have significantly improved their position relative to BRC winners. As a matter of fact, ten more BioRegios were formed by 2005 (for details, see Engel and Heneric 2005). In addition to the efforts of the Federal Government, many Federal States governments promote BioRegios within the state. At this stage, we cannot fairly conclude that regionalized technological policy lacks efficiency in the long term. We believe that improvements in - particularly - non-participants are the key explanation for the absence of long-term effects of BRC.

Finally, switching to the evaluation of the BPC, Panel $\mathrm{C}$ shows the findings for BPC winners and the two comparison groups. Consistently with the findings discussed above, here we obtain fairly small effects when comparing winning and other regions, as the winners only appear to perform better in terms of raising collaborative R\&D projects. Nevertheless, the "selection of the fittest" also seems to works in both stages of the competitions, since the BPC winners also perform significantly better than non-winning participants during the treatment period for the latter contest. The estimated elasticity of the DiD term is about the same size as the effect identified for the BRC. This is an important finding, since one might expect the performance of the winners at the second stage to be characterized by lower differences with the non-winners. The smaller treatment effects found for BPC winners relative to non-participants may be partly due the consolidation phase going on in the industry throughout the second half of the last decade. Although we control for a common time trend among all groups, which turns out to be significantly negative according to Table 8 , throughout this consolidation period the chances to realize excess returns for funded regions may also have been limited.

We finally report some details about our estimation setup according to Tables 8-11. Regarding the appropriate functional form, in most specifications the ZIP model is favoured over the Poisson model based on information criteria (AIC, BIC) as well as on the Vuong (1989) non-nested test for the Poisson and ZIP model. A significant test statistic indicates that the zero-inflated model fits the data better. To highlight the likely differences between the standard Poisson and the ZIP model, Figure 1 additionally plots the in-sample forecast error of the Poisson (PRM) and ZIP model for the observations close to zero in the patent model (BRC participants versus other districts). The figure shows that the ZIP is superior to the PRM in all predictions, in particular for values close to zero. As a key explanatory variable in the Probit specification, we use the share of regional hightech startups as an indicator of the innovative climate for a region that either supports $R \& D$ or not. In all specifications, this variable turns out to be statistically significant and of the expected sign. Also, the remaining variables in the Poisson part of the model 
mostly reflect our ex-ante expectations: that is, both the share of $\mathrm{R} \& \mathrm{D}$ employees and the export share have a positive impact on R\&D activity. Moreover, the total number of firms, the variables measuring general agglomeration (e.g., population density), and sectoral concentration indices (and their squared values) are statistically significant.

Figure 1: Prediction errors in Poisson (PRM) and ZIP model for R\&D projects



\section{Augmenting the model: The role of spatial dependence}

In this section, we aim to investigate the role played by spatial autocorrelation (SAC) in our empirical models. Recently, Grimpe and Patuelli (2010) have shown, for the case of the German nanomaterials sector, that SAC may be highly relevant in the estimation of NUTS-3-level regional knowledge production functions using patents as a dependent variable. According to Cliff \& Ord (1981) SAC can be defined as the correlation among observations of a georeferenced variable stemming from to their direct proximity. SAC may be due to self-correlation, omitted/unobserved variables, or spatial spillover effects. Disregarding cross sectional dependence in the data may indeed lead to biased estimation results (Anselin 1988) and therefore to inappropriate model interpretation. In line with Grimpe and Patuelli (2010), we thus include an eigenvector-based spatial filter in our models, in order to account for the potentially uneven - and spatially correlated - regional 
Table 8: Estimation Results for Patent Applications (Treatment Period)

\begin{tabular}{|c|c|c|c|c|c|c|}
\hline Sample & BRC1 & & BRC2 & & BPC & \\
\hline D1 & $0.682^{* * *}$ & $(0.0375)$ & $0.745^{* * *}$ & $(0.0376)$ & $0.879^{* * *}$ & $(0.0315)$ \\
\hline D2 & $0.521^{* * *}$ & $(0.3577)$ & $0.542^{* * *}$ & $(0.0358)$ & $0.580^{* * *}$ & $(0.0267)$ \\
\hline D3 & & & $0.261^{* * *}$ & $(0.0486)$ & & \\
\hline $\mathrm{T}$ & $0.727^{* * *}$ & $(0.0207)$ & $0.520^{* * *}$ & $(0.0211)$ & $-0.733^{* * *}$ & $(0.0197)$ \\
\hline DT1 & $0.465^{* * *}$ & $(0.0383)$ & $0.378^{* * *}$ & $(0.0400)$ & -0.046 & $(0.0420)$ \\
\hline $\mathrm{DT} 2$ & $-0.079^{* *}$ & $(0.0398)$ & $-0.099^{* *}$ & $(0.0419)$ & $-0.401^{* * *}$ & $(0.0421)$ \\
\hline DT3 & & & $0.706^{* * *}$ & $(0.0502)$ & & \\
\hline Number of Firms & $0.002^{* * *}$ & $(0.0001)$ & $0.003^{* * *}$ & $(0.0001)$ & $0.002^{* * *}$ & $(0.0001)$ \\
\hline Average Firm size & $0.001^{* * *}$ & $(0.0001)$ & $0.001^{* * *}$ & $(0.0002)$ & $-0.001^{* * *}$ & $(0.0002)$ \\
\hline Export Share & $0.008^{* * *}$ & $(0.0008)$ & $0.007^{* * *}$ & $(0.0006)$ & $0.011^{* * *}$ & $(0.0007)$ \\
\hline R\&D Employment & $0.064^{* * *}$ & $(0.0061)$ & $0.018^{* * *}$ & $(0.0063)$ & 0.006 & $(0.0074)$ \\
\hline Population Density & $0.072^{* * *}$ & $(0.0113)$ & $0.041^{* * *}$ & $(0.0118)$ & $0.167^{* * *}$ & $(0.0116)$ \\
\hline Sectoral Specialization 2 & 0.191 & $(0.1683)$ & $-0.434^{* *}$ & $(0.1781)$ & $-0.569^{* * *}$ & $(0.1898)$ \\
\hline Sectoral Specialization 3 & $-1.222^{* * *}$ & $(0.1432)$ & $-0.386^{* *}$ & $(0.1643)$ & $-0.585^{* * *}$ & $(0.1520)$ \\
\hline Sectoral Specialization 4 & 0.166 & $(0.1024)$ & $-0.183^{*}$ & $(0.1054)$ & 0.066 & $(0.1103)$ \\
\hline$(\text { Sectoral Specialization } 2)^{2}$ & $-0.032^{* *}$ & $(0.0133)$ & 0.019 & $(0.0141)$ & $0.028^{*}$ & $(0.0150)$ \\
\hline$(\text { Sectoral Specialization } 3)^{2}$ & $0.128^{* * *}$ & $(0.0133)$ & $0.055^{* * *}$ & $(0.0152)$ & $0.068^{* * *}$ & $(0.0143)$ \\
\hline$(\text { Sectoral Specialization } 4)^{2}$ & -0.012 & $(0.0109)$ & $0.033^{* * *}$ & $(0.0111)$ & -0.001 & $(0.0118)$ \\
\hline Ellison-Glaeser 2 & $0.059^{* * *}$ & $(0.0034)$ & $0.049^{* * *}$ & $(0.0035)$ & $0.078^{* * *}$ & $(0.0042)$ \\
\hline Ellison-Glaeser 3 & $0.151^{* * *}$ & $(0.0097)$ & $0.100^{* * *}$ & $(0.0105)$ & $0.093^{* * *}$ & $(0.0104)$ \\
\hline Ellison-Glaeser 4 & 0.019 & $(0.0123)$ & $0.101^{* * *}$ & $(0.0131)$ & $0.071^{* * *}$ & $(0.0128)$ \\
\hline$(\text { Ellison-Glaeser } 2)^{2}$ & $-0.001^{* * *}$ & $(0.0001)$ & $-0.001^{* * *}$ & $(0.0001)$ & $-0.002^{* * *}$ & $(0.0001)$ \\
\hline$(\text { Ellison-Glaeser } 3)^{2}$ & $-0.003^{* * *}$ & $(0.0003)$ & $-0.002^{* * *}$ & $(0.0003)$ & $-0.001^{* * *}$ & $(0.0003)$ \\
\hline$(\text { Ellison-Glaeser } 4)^{2}$ & $-0.001^{* *}$ & $(0.0006)$ & $-0.004^{* * *}$ & $(0.0007)$ & $-0.002^{* * *}$ & $(0.0007)$ \\
\hline \multicolumn{7}{|l|}{ Probit (ZIP) } \\
\hline Start-up (High-Tech) & $0.569^{* *}$ & $(0.2225)$ & $1.078^{* * *}$ & $(0.3473)$ & $0.989^{* *}$ & $(0.3929)$ \\
\hline Start-up (all) & $-0.045^{* *}$ & $(0.0164)$ & $-0.095^{* * *}$ & $(0.0274)$ & $-0.125^{* * *}$ & $(0.0346)$ \\
\hline $\mathrm{DiDiD}=\mathrm{DT} 1-\mathrm{DT} 2$ & $0.545^{* * *}$ & $(0.0047)$ & $0.478^{* * *}$ & $(0.0498)$ & $0.355^{* * *}$ & $(0.0531)$ \\
\hline DiDiD2 = DT1 - DT3 & & & $-0.327^{* * *}$ & $(0.0570)$ & & \\
\hline $\operatorname{diff}(\mathrm{BIC})$ & 3768.5 & $(\mathrm{ZIP})$ & 4062.0 & $(\mathrm{ZIP})$ & 3741.1 & $(\mathrm{ZIP})$ \\
\hline $\operatorname{diff}(\mathrm{AIC})$ & 4.62 & $(\mathrm{ZIP})$ & 4.87 & $(\mathrm{ZIP})$ & 4.62 & $(\mathrm{ZIP})$ \\
\hline Vuong test ( $p$-value) & 5.87 & $(0.00)$ & 7.26 & $(0.00)$ & 6.44 & $(0.00)$ \\
\hline No. of obs. & $818^{a}$ & & 836 & & $812^{a}$ & \\
\hline
\end{tabular}

Notes: ******* indicate statistical significance at the 1,5 and $10 \%$ level. Standard errors in brackets. Specialization and Ellison-Glaeser indices: $2=$ manufacturing, $3=$ business-related services, $4=$ household-related services. Dummy variables: $\mathrm{D} 1=$ winners, $\mathrm{D} 2=$ participants (in the $\mathrm{BRC} 2$ sample: $\mathrm{D} 2=$ participants net of $\mathrm{BPC}$ winner, $\mathrm{D} 3=\mathrm{BPC}$ winner). DT1 to DT3 indicate the DiD interaction term calculated as the product of the level dummies and the common time trend T. Number of observations: ${ }^{a}=$ BPC winners dropped in sample BRC1, BRC winners dropped in sample BPC. For diff(BIC) and dif(AIC) the expression in brackets indicates the preferred model as either ZIP or PRM. 
Table 9: Estimation Results for all R\&D Projects (Treatment Period)

\begin{tabular}{|c|c|c|c|c|c|c|}
\hline Sample & BRC1 & & BRC2 & & BPC & \\
\hline D1 & $1.099^{* * *}$ & $(0.0617)$ & $1.186^{* * *}$ & $(0.0598)$ & $1.650^{* * *}$ & $(0.0441)$ \\
\hline D2 & $0.656^{* * *}$ & $(0.0543)$ & $0.677^{* * *}$ & $(0.0538)$ & $0.779^{* * *}$ & $(0.0420)$ \\
\hline D3 & & & $1.526^{* * *}$ & $(0.0542)$ & & \\
\hline $\mathrm{T}$ & $0.228^{* * *}$ & $(0.0407)$ & $-0.121^{* *}$ & $(0.0493)$ & $0.127^{* * *}$ & $(0.0331)$ \\
\hline DT1 & $0.357^{* * *}$ & $(0.0615)$ & $0.173^{* *}$ & $(0.0718)$ & 0.076 & $(0.473)$ \\
\hline $\mathrm{DT} 2$ & 0.041 & $(0.0624)$ & $-0.176^{* *}$ & $(0.0740)$ & $-0.204^{* * *}$ & $(0.0510)$ \\
\hline DT3 & & & $-0.245^{* * *}$ & $(0.0706)$ & & \\
\hline Number of Firms & $0.002^{* * *}$ & $(0.0001)$ & $0.002^{* * *}$ & $(0.0001)$ & $0.002^{* * *}$ & $(0.0001)$ \\
\hline Average Firm size & $-0.002^{* * *}$ & $(0.0003)$ & $-0.001^{* * *}$ & $(0.0003)$ & $-0.003^{* * *}$ & $(0.0004)$ \\
\hline Export Share & $0.018^{* * *}$ & $(0.0017)$ & $0.007^{* * *}$ & $(0.0008)$ & $0.010^{* * *}$ & $(0.0008)$ \\
\hline R\&D Employment & $0.086^{* * *}$ & $(0.0111)$ & $0.089^{* * *}$ & $(0.0114)$ & $0.108^{* * *}$ & $(0.0100)$ \\
\hline Population Density & $0.237^{* * *}$ & $(0.0244)$ & $0.293^{* * *}$ & $(0.0237)$ & $0.246^{* * *}$ & $(0.0186)$ \\
\hline Sectoral Specialization 2 & $-1.038^{* *}$ & $(0.3965)$ & $-2.427^{* * *}$ & $(0.4196)$ & $-4.258^{* * *}$ & $(0.3185)$ \\
\hline Sectoral Specialization 3 & $-2.379^{* * *}$ & $(0.2771)$ & $-1.947^{* * *}$ & $(0.3227)$ & $-1.958^{* * *}$ & $(0.2767)$ \\
\hline Sectoral Specialization 4 & $1.099^{* * *}$ & $(0.2137)$ & $0.920^{* * *}$ & $(0.2296)$ & $1.022^{* * *}$ & $(0.1875)$ \\
\hline$(\text { Sectoral Specialization } 2)^{2}$ & $0.072^{* *}$ & $(0.0311)$ & $0.177^{* * *}$ & $(0.0332)$ & $0.3182^{* * *}$ & $(0.0254)$ \\
\hline$(\text { Sectoral Specialization } 3)^{2}$ & $0.219^{* * *}$ & $(0.0265)$ & $0.181^{* * *}$ & $(0.0308)$ & $0.148^{* * *}$ & $(0.0274)$ \\
\hline$(\text { Sectoral Specialization } 4)^{2}$ & $-0.058^{* * *}$ & $(0.0218)$ & $-0.052^{* *}$ & $(0.0233)$ & $-0.071^{* * *}$ & $(0.0195)$ \\
\hline Ellison-Glaeser 2 & $-0.065^{* * *}$ & $(0.0066)$ & $-0.019^{* * *}$ & $(0.0062)$ & $0.036^{* * *}$ & $(0.0065)$ \\
\hline Ellison-Glaeser 3 & $-0.202^{* * *}$ & $(0.0203)$ & $-0.236^{* * *}$ & $(0.0231)$ & $-0.231^{* * *}$ & $(0.0198)$ \\
\hline Ellison-Glaeser 4 & $0.225^{* * *}$ & $(0.0264)$ & $0.289^{* * *}$ & $(0.0273)$ & $0.318^{* * *}$ & $(0.0224)$ \\
\hline$(\text { Ellison-Glaeser } 2)^{2}$ & $0.001^{* * *}$ & $(0.0001)$ & -0.0002 & $(0.0001)$ & $-0.001^{* * *}$ & $(0.0001)$ \\
\hline$(\text { Ellison-Glaeser } 3)^{2}$ & $0.005^{* * *}$ & $(0.0006)$ & $0.005^{* * *}$ & $(0.0007)$ & $0.006^{* * *}$ & $(0.0006)$ \\
\hline$(\text { Ellison-Glaeser } 4)^{2}$ & $-0.005^{* * *}$ & $(0.0011)$ & $-0.007^{* * *}$ & $(0.0012)$ & $-0.008^{* * *}$ & $(0.0011)$ \\
\hline \multicolumn{7}{|l|}{ Probit (ZIP) } \\
\hline Start-up (High-Tech) & $1.104^{* * *}$ & $(0.2107)$ & $1.025^{* * *}$ & $(0.2076)$ & $1.113^{* * *}$ & $(0.2242)$ \\
\hline Start-up (all) & $-0.051^{* * *}$ & $(0.0153)$ & $-0.053^{* * *}$ & $(0.0150)$ & $-0.084^{* * *}$ & $(0.0182)$ \\
\hline DiDiD = DT1 - DT2 & $0.316^{* * *}$ & $(0.0676)$ & $0.349^{* * *}$ & $(0.0772)$ & $0.280^{* * *}$ & $(0.0524)$ \\
\hline DiDiD2 = DT1 - DT3 & & & $0.419^{* * *}$ & $(0.0745)$ & & \\
\hline $\operatorname{diff}(\mathrm{BIC})$ & 2677.1 & $(\mathrm{ZIP})$ & 2212.1 & $(\mathrm{ZIP})$ & 3173.9 & $(\mathrm{ZIP})$ \\
\hline $\operatorname{diff}(\mathrm{AIC})$ & 3.31 & $(\mathrm{ZIP})$ & 2.67 & $(\mathrm{ZIP})$ & 3.92 & $(\mathrm{ZIP})$ \\
\hline Vuong test ( $p$-value) & 8.41 & $(0.00)$ & 8.27 & $(0.00)$ & 8.16 & $(0.00)$ \\
\hline No. of obs. & $812^{a}$ & & 834 & & $812^{a}$ & \\
\hline
\end{tabular}

Notes: ******* indicate statistical significance at the 1,5 and $10 \%$ level. Standard errors in brackets. Specialization and Ellison-Glaeser indices: $2=$ manufacturing, $3=$ business-related services, $4=$ household-related services. Dummy variables: $\mathrm{D} 1=$ winners, $\mathrm{D} 2=$ participants (in the $\mathrm{BRC} 2$ sample: $\mathrm{D} 2=$ participants net of $\mathrm{BPC}$ winner, $\mathrm{D} 3=\mathrm{BPC}$ winner). DT1 to DT3 indicate the DiD interaction term calculated as the product of the level dummies and the common time trend T. Number of observations: ${ }^{a}=$ BPC winners dropped in sample BRC1, BRC winners dropped in sample BPC. For diff(BIC) and dif(AIC) the expression in brackets indicates the preferred model as either ZIP or PRM. 
Table 10: Estimation Results for collaborative R\&D Projects (Treatment Period)

\begin{tabular}{|c|c|c|c|c|c|c|}
\hline Sample & BRC1 & & BRC2 & & BPC & \\
\hline D1 & $0.731^{* * *}$ & $(0.0962)$ & $0.897^{* * *}$ & $(0.0950)$ & $1.173^{* * *}$ & $(0.0644)$ \\
\hline D2 & $0.318^{* * *}$ & $(0.0872)$ & $0.352^{* * *}$ & $(0.0866)$ & $0.431^{* * *}$ & $(0.0605)$ \\
\hline D3 & & & $1.128^{* * *}$ & $(0.0879)$ & & \\
\hline $\mathrm{T}$ & $0.554^{* * *}$ & $(0.0647)$ & $0.114^{*}$ & $(0.0708)$ & $0.257^{* * *}$ & $(0.0450)$ \\
\hline DT1 & $0.399^{* * *}$ & $(0.0929)$ & $0.360^{* * *}$ & $(0.0865)$ & $0.328^{* * *}$ & $(0.0654)$ \\
\hline DT2 & 0.054 & $(0.0962)$ & -0.043 & $(0.1085)$ & 0.022 & $(0.0699)$ \\
\hline DT3 & & & -0.116 & $(0.1036)$ & & \\
\hline Number of Firms & $0.003^{* * *}$ & $(0.0002)$ & $0.003^{* * *}$ & $(0.0002)$ & $0.002^{* * *}$ & $(0.0001)$ \\
\hline Average Firm size & 0.0006 & $(0.0004)$ & $0.001^{*}$ & $(0.0005)$ & $-0.002^{* * *}$ & $(0.0005)$ \\
\hline Export Share & $0.019^{* * *}$ & $(0.0025)$ & $0.002^{*}$ & $(0.0012)$ & $0.009^{* * *}$ & $(0.0012)$ \\
\hline R\&D Employment & $0.041^{* * *}$ & $(0.0153)$ & $0.036^{* *}$ & $(0.0163)$ & $0.082^{* * *}$ & $(0.0130)$ \\
\hline Population Density & 0.022 & $(0.0354)$ & $0.068^{* *}$ & $(0.0349)$ & $0.101^{* * *}$ & $(0.0254)$ \\
\hline Sectoral Specialization 2 & 0.796 & $(0.5570)$ & -0.485 & $(0.620)$ & $-4.111^{* * *}$ & $(0.4407)$ \\
\hline Sectoral Specialization 3 & $-1.818^{* * *}$ & $(0.3806)$ & $-1.294^{* * *}$ & $(0.4367)$ & $-0.750^{*}$ & $(0.3826)$ \\
\hline Sectoral Specialization 4 & $0.854^{* * *}$ & $(0.3148)$ & 0.469 & $(0.3517)$ & $0.0945^{* * *}$ & $(0.2632)$ \\
\hline$(\text { Sectoral Specialization } 2)^{2}$ & $-0.074^{*}$ & $(0.0436)$ & 0.027 & $(0.0491)$ & $0.0310^{* * *}$ & $(0.0354)$ \\
\hline$(\text { Sectoral Specialization } 3)^{2}$ & $0.154^{* * *}$ & $(0.0371)$ & $0.114^{* *}$ & $(0.0448)$ & 0.020 & $(0.0383)$ \\
\hline$(\text { Sectoral Specialization } 4)^{2}$ & -0.028 & $(0.0323)$ & -0.001 & $(0.0357)$ & $0.060^{*}$ & $(0.0275)$ \\
\hline Ellison-Glaeser 2 & $-0.055^{* * *}$ & $(0.0094)$ & -0.006 & $(0.0094)$ & $0.056^{* * *}$ & $(0.0092)$ \\
\hline Ellison-Glaeser 3 & $-0.221^{* * *}$ & $(0.0281)$ & $-0.265^{* * *}$ & $(0.0329)$ & $-0.165^{* * *}$ & $(0.0261)$ \\
\hline Ellison-Glaeser 4 & $0.311^{* * *}$ & $(0.0364)$ & $0.334^{* * *}$ & $(0.0388)$ & $0.259^{* * *}$ & $(0.0288)$ \\
\hline$(\text { Ellison-Glaeser } 2)^{2}$ & $0.001^{* *}$ & $(0.0002)$ & $-0.0005^{* *}$ & $(0.0003)$ & $-0.002^{* * *}$ & $(0.0002)$ \\
\hline$(\text { Ellison-Glaeser } 3)^{2}$ & $0.004^{* * *}$ & $(0.0008)$ & $0.005^{* * *}$ & $(0.0010)$ & $0.004^{* * *}$ & $(0.0008)$ \\
\hline$(\text { Ellison-Glaeser } 4)^{2}$ & $-0.007^{* * *}$ & $(0.0016)$ & $-0.007^{* * *}$ & $(0.0017)$ & $-0.003^{* *}$ & $(0.001)$ \\
\hline \multicolumn{7}{|l|}{ Probit (ZIP) } \\
\hline Start-up (High-Tech) & $1.194^{* * *}$ & $(0.243)$ & $1.249^{* * *}$ & $(0.2399)$ & $1.131^{* * *}$ & $(0.2370)$ \\
\hline Start-up (all) & $-0.033^{* *}$ & $(0.0166)$ & $-0.033^{* *}$ & $(0.0161)$ & $-0.062^{* * *}$ & $(0.0186)$ \\
\hline $\mathrm{DiDiD}=\mathrm{DT} 1-\mathrm{DT} 2$ & $0.345^{* * *}$ & $(0.0995)$ & $0.403^{* * *}$ & $(0.1109)$ & $0.307^{* * *}$ & $(0.0722)$ \\
\hline DiDiD2 = DT1 - DT3 & & & $0.475^{* * *}$ & $(0.1068)$ & & \\
\hline $\operatorname{diff}(\mathrm{BIC})$ & 2017.8 & $(\mathrm{ZIP})$ & 1472.3 & $(\mathrm{ZIP})$ & 2551.7 & (ZIP) \\
\hline $\operatorname{diff}(\mathrm{AIC})$ & 2.50 & $(\mathrm{ZIP})$ & 1.78 & $(\mathrm{ZIP})$ & 3.16 & $(\mathrm{ZIP})$ \\
\hline Vuong test ( $p$-value) & 7.80 & $(0.00)$ & 7.19 & $(0.00)$ & 7.98 & $(0.00)$ \\
\hline No. of obs. & $812^{a}$ & & 834 & & $812^{a}$ & \\
\hline
\end{tabular}

Notes: $* * *, * * *$ indicate statistical significance at the 1, 5 and $10 \%$ level. Standard errors in brackets. Specialization and Ellison-Glaeser indices: $2=$ manufacturing, $3=$ business-related services, $4=$ household-related services. Dummy variables: $\mathrm{D} 1=$ winners, $\mathrm{D} 2=$ participants (in the $\mathrm{BRC} 2$ sample: $\mathrm{D} 2=$ participants net of $\mathrm{BPC}$ winner, $\mathrm{D} 3=\mathrm{BPC}$ winner). DT1 to DT3 indicate the DiD interaction term calculated as the product of the level dummies and the common time trend T. Number of observations: ${ }^{a}=$ BPC winners dropped in sample BRC1, BRC winners dropped in sample BPC. For diff(BIC) and dif(AIC) the expression in brackets indicates the preferred model as either ZIP or PRM. 
Table 11: BRC1-Estimation Results for R\&D Projects (Post-Treatment Period)

\begin{tabular}{|c|c|c|c|c|}
\hline \multirow{2}{*}{$\begin{array}{l}\text { Sample: BRC1 } \\
\text { D1 }\end{array}$} & \multicolumn{2}{|c|}{ All Projects } & \multicolumn{2}{|c|}{ Collaborative } \\
\hline & $1.037^{* * *}$ & $(0.0618)$ & $0.644^{* * *}$ & $(0.0962)$ \\
\hline D2 & $0.607^{* * *}$ & $(0.0543)$ & $0.223^{* *}$ & $(0.0881)$ \\
\hline $\mathrm{T}$ & $0.244^{* * *}$ & $(0.0443)$ & $0.504^{* * *}$ & $(0.0688)$ \\
\hline DT1 & 0.094 & $(0.0638)$ & $0.224^{* *}$ & $(0.0959)$ \\
\hline $\mathrm{DT} 2$ & $-0.117^{*}$ & $(0.0638)$ & 0.134 & $(0.0969)$ \\
\hline Number of Firms & $0.003^{* * *}$ & $(0.0001)$ & $0.003^{* * *}$ & $(0.0002)$ \\
\hline Average Firm size & 0.0001 & $(0.0002)$ & $0.002^{* * *}$ & $(0.0004)$ \\
\hline Export Share & $0.013^{* * *}$ & $(0.0016)$ & $0.015^{* * *}$ & $(0.0022)$ \\
\hline R\&D Employment & $0.087^{* * *}$ & $(0.0115)$ & $0.035^{* *}$ & $(0.0159)$ \\
\hline Population Density & $0.232^{* * *}$ & $(0.0245)$ & $0.082^{* *}$ & $(0.0366)$ \\
\hline Sectoral Specialization 2 & $-1.616^{* * *}$ & $(0.4112)$ & $-1.177^{* *}$ & $(0.5699)$ \\
\hline Sectoral Specialization 3 & $-1.7199^{* * *}$ & $(0.2883)$ & $-1.885^{* * *}$ & $(0.4011)$ \\
\hline Sectoral Specialization 4 & $1.094^{* * *}$ & $(0.2239)$ & 0.0033 & $(0.3227)$ \\
\hline$(\text { Sectoral Specialization } 2)^{2}$ & $0.0995^{* * *}$ & $(0.0322)$ & $0.065^{* * *}$ & $(0.0446)$ \\
\hline$(\text { Sectoral Specialization } 3)^{2}$ & $0.152^{* * *}$ & $(0.0277)$ & $0.160^{* * *}$ & $(0.0393)$ \\
\hline$(\text { Sectoral Specialization } 4)^{2}$ & $-0.051^{* *}$ & $(0.0229)$ & $0.068^{* *}$ & $(0.0329)$ \\
\hline Ellison-Glaeser 2 & $-0.047^{* * *}$ & $(0.0065)$ & $-0.027^{* * *}$ & $(0.0093)$ \\
\hline Ellison-Glaeser 3 & $-0.262^{* * *}$ & $(0.0225)$ & $-0.223^{* * *}$ & $(0.0304)$ \\
\hline Ellison-Glaeser 4 & $0.358^{* * *}$ & $(0.0287)$ & $0.347^{* * *}$ & $(0.0385)$ \\
\hline$(\text { Ellison-Glaeser } 2)^{2}$ & 0.001 & $(0.0013)$ & $-0.0003^{*}$ & $(0.0001)$ \\
\hline$(\text { Ellison-Glaeser } 3)^{2}$ & $0.005^{* * *}$ & $(0.0007)$ & $0.004^{* * *}$ & $(0.0009)$ \\
\hline$(\text { Ellison-Glaeser } 4)^{2}$ & $-0.010^{* * *}$ & $(0.0013)$ & $-0.008^{* * *}$ & $(0.0017)$ \\
\hline \multicolumn{5}{|l|}{ Probit (ZIP) } \\
\hline Start-up (High-Tech) & $1.099^{* * *}$ & $(0.2165)$ & $1.557^{* * *}$ & $(0.2655)$ \\
\hline Start-up (all) & $-0.057^{* * *}$ & $(0.0151)$ & $-0.040^{* *}$ & $(0.0167)$ \\
\hline DiDiD = DT1 - DT2 & $0.212^{* * *}$ & $(0.0707)$ & 0.091 & $(0.1015)$ \\
\hline $\operatorname{diff}(\mathrm{BIC})$ & 2708.9 & $(\mathrm{ZIP})$ & 1821.4 & $(\mathrm{ZIP})$ \\
\hline $\operatorname{diff}(\mathrm{AIC})$ & 3.379 & $(\mathrm{ZIP})$ & 2.27 & $(\mathrm{ZIP})$ \\
\hline Vuong test ( $p$-value) & 8.17 & $(0.00)$ & 7.64 & $(0.00)$ \\
\hline No. of obs. & $806^{a}$ & & $806^{a}$ & \\
\hline
\end{tabular}

Notes: $* * *, * * *$ indicate statistical significance at the 1, 5 and $10 \%$ level. Standard errors in brackets. Specialization and Ellison-Glaeser indices: $2=$ manufacturing, $3=$ business-related services, $4=$ household-related services. Dummy variables: D1 = winners, D2 = participants (in the BRC2 sample: D2= BPC winners, D3 = further participants). DT1 to DT3 indicate the DiD interaction term calculated as the product of the level dummies and the common time trend $\mathrm{T}$. Number of observations: ${ }^{a}=$ BPC winners dropped. For diff(BIC) and dif(AIC) the expression in brackets indicates the preferred model as either ZIP or PRM. 
distribution of biotech activities in Germany. Hence, the spatial filter can also be seen as a surrogate for unobserved fixed effects and its inclusion may limit the bias stemming from omitted variables (Patuelli et al. 2009).

The advantage of spatial filtering with respect to other spatial regression techniques is that the spatial filtering approach does not require an assumption of normality or other estimation restrictions, and can be straightforwardly applied to regression equations with any underlying distribution (including Logit/Probit and Poisson regression). We use an approach developed by Griffith $(2000,2003)$, which makes use of the commonly known Moran's $I$ (MI) statistic. ${ }^{9}$ The latter is defined as an indicator of the average spatial association, between $N$ cross-sectional units, for variable $y$ and on the basis of the elements $w$ of a spatial weights matrix $W$, according to:

$$
M I=\frac{N}{S_{0}} \frac{\sum_{i=1}^{N} \sum_{j=1}^{N} w_{i j}\left(y_{i}-\bar{y}_{t}\right)\left(y_{j}-\bar{y}\right)}{\sum_{i=1}^{N}\left(y_{i}-\bar{y}\right)^{2}}
$$

where $S_{0}=\left(\sum_{i=1}^{N} \sum_{j=1}^{N} w_{i j}\right)$ is a measure of the overall connectivity of the geographical system, and $\bar{y}=\left(\sum_{i=1}^{N} y_{i} / N\right)$. This measure captures the correlation between values of $y$ and of its spatial lag $W \times y$ for a given time period. Positive values of $M I$ imply positive $\mathrm{SAC}$, that is, similar observations of the variable examined tend to be found for regions that are geographically close. The opposite holds for negative values of MI, which is a rarer (or often hidden, see, e.g., Griffith 2006) phenomenon. For empirical operationalization, a spatial weights matrix $W$ of dimension $(N \times N)$ is required. The empirical literature has proposed many different ways to handle SAC, generally to approximate distance decay. The simplest - and often effective - strategy is to use a binary spatial weights matrix where a $(i, j)$ unit takes the value of 1 if a certain criterion for spatial proximity between cross-sectional units $i$ and $j$ is fulfilled, and zero otherwise. One standard way is to choose common geographical borders as a geographical discrimination criterion, but the choice is not limited to this dimension.

To get a first indication about the role played by spatial dependence for our two outcome measures, in Table 12 we compute the corresponding Moran's I values based on a border based spatial neighbourhood matrix. ${ }^{10}$

Interestingly, while the regional distribution of patent applications indeed shows positive spatial autocorrelation, the regional distribution of publicly funded research projects

\footnotetext{
${ }^{9}$ Additionally, while Getis's approach transforms the original data into a structural and a pure spatial component, Griffith's approach leaves the original data unchanged, while adding eigenvector-based regression components to the model.

${ }^{10} \mathrm{We}$ also used metric distances in kilometers of driving time between NUTS-3 districts. The obtained results remain stable; further details can be obtained from the authors upon request.
} 
Table 12: Moran's I value for outcome variables and different periods in BRC1 sample

\begin{tabular}{llll}
\hline \hline & Patents & $\begin{array}{l}\text { All R\&D } \\
\text { Projects }\end{array}$ & $\begin{array}{l}\text { Collaborative } \\
\text { R\&D Projects }\end{array}$ \\
\hline Pre-Treatment & $0.214^{* * *}$ & 0.009 & 0.005 \\
& $(0.00)$ & $(0.45)$ & $(0.38)$ \\
Treatment & $0.202^{* * *}$ & 0.017 & 0.030 \\
& $(0.00)$ & $(0.24)$ & $(0.11)$ \\
Post-Treatment & n.a. & 0.009 & 0.005 \\
& & $(0.32)$ & $(0.39)$ \\
\hline \hline
\end{tabular}

Notes: $* * *, * *, *$ indicate statistical significance at the 1,5 and $10 \%$ level. p-values in brackets.

does not exhibit any particular spatial pattern (both for the aggregate number and for the subgroup of collaborative projects). The latter results may be seen as a further hint to the strong distributive element included in the allocation of public projects. Having shown that spatial dependence is highly present in the patent data model, we finally reestimate the model based on the three samples (BRC1, BRC2, BPC). We are particularly interested to see whether the results obtained from the aspatial analysis hold once we include a set of MI-based spatial filters. The approach extracts orthogonal and uncorrelated numerical components (eigenvectors) from the projection matrix of the exogenously specified spatial weights matrix $\mathbf{W} .^{11}$ The extracted eigenvectors represent all possible patterns of latent spatial autocorrelation implied by the chosen form of $\mathbf{W}$. The latter has to be first transformed according to:

$$
\left(\mathbf{I}-\mathbf{1 1} \mathbf{1}^{T} / N\right) \mathbf{W}\left(\mathbf{I}-\mathbf{1 1}^{T} / N\right),
$$

where $I$ is an $(N \times N)$ identity matrix, and 1 is an $(N \times 1)$ vector containing ones. The extraction according to Eq.(5) then gives a set of $N$ eigenvectors $\left(e_{i}\right.$ with $\left.i=, 1 \ldots, N\right)$, which have the properties of maximizing SAC, while being orthogonal to the previously extracted eigenvectors. To reduce the total number of included eigenvectors in the regression equation, we follow Grimpe and Patuelli (2010) and first select a subset of candidate eigenvectors according to the following threshold: $M I\left(e_{i}\right) / \max _{i}\left[M I\left(e_{i}\right)\right]>0.25$, where $M I\left(e_{i}\right)$ is the MI computed on a generic eigenvector $i .{ }^{12}$ A graphical presentation of the regional distribution of biotechnology patent applications for 1991-1997 and 1998-2006, as well as the first two extracted candidate eigenvectors $(E 1, E 2)$ is given in Figure 2.

\footnotetext{
${ }^{11}$ We do not aim to give a detailed discussion of the computational details of the eigenvector-based spatial filtering at this point (the reader can refer, e.g., to Griffith 2003 and Grimpe and Patuelli, 2010).

${ }^{12}$ This threshold level corresponds to $95 \%$ of variance explained in a regression of a generic variable $Y$ on $W Y$.
} 
Figure 2: Spatial distribution of patent activity in 1991-1997 and 1998-2006; eigenvectors E1 and E2
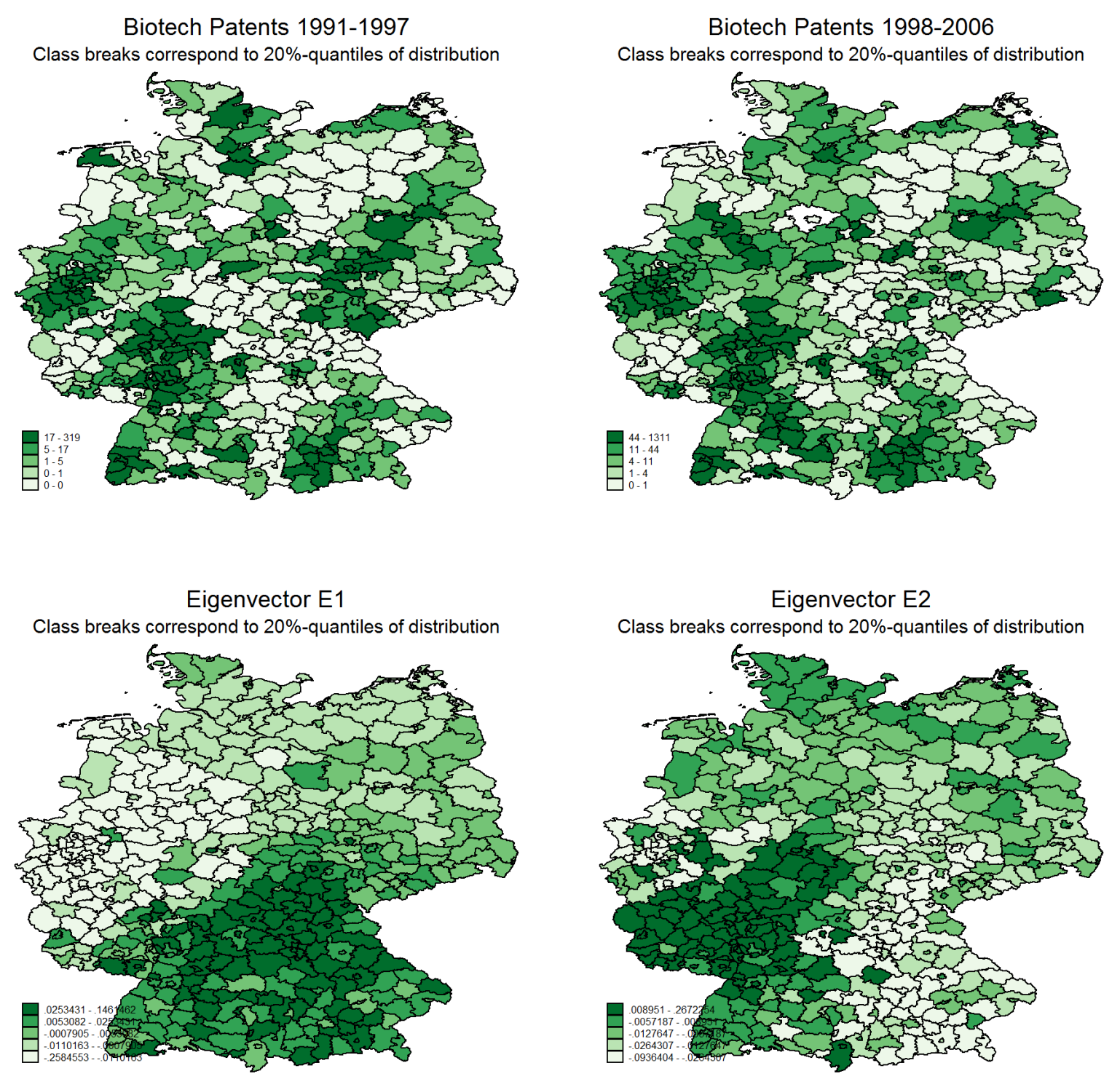

The candidate set is then included in the regression model and a stepwise estimation approach is carried out, starting from the full model specification and subsequently excluding non-significant eigenvectors while model-based variables are kept as part of the minimum model. ${ }^{13}$ The results in Table 13 show that the included eigenvectors are

\footnotetext{
${ }^{13}$ As Grimpe and Patuelli (2010) have shown, the stepwise elimination of non-significant eigenvectors may tend to overfit the model. We therefore choose a relatively high significance level (99 per cent) for the underlying likelihood ratio test of variable exclusion. Additionally, we have only included the set of eigenvectors in the Poisson part of the ZIP.
} 
Table 13: Re-Estimation of patent models including a spatial filter (treatment period)

\begin{tabular}{|c|c|c|c|c|c|c|}
\hline Sample & \multicolumn{2}{|l|}{ BRC1 } & \multicolumn{2}{|l|}{ BRC2 } & \multicolumn{2}{|l|}{ BPC } \\
\hline D1 & $0.779^{* * *}$ & $(0.0463)$ & $0.971^{* * *}$ & $(0.0452)$ & $1.715^{* * *}$ & $(0.0667)$ \\
\hline D2 & $0.649^{* * *}$ & $(0.0463)$ & $0.736^{* * *}$ & $(0.0766)$ & $0.793^{* * *}$ & $(0.0380)$ \\
\hline D3 & & & $0.815^{* * *}$ & $(0.0462)$ & & \\
\hline $\mathrm{T}$ & $0.868^{* * *}$ & $(0.0220)$ & $0.575^{* * *}$ & $(0.0217)$ & $-0.722^{* * *}$ & $(0.0209)$ \\
\hline DT1 & $0.333^{* * *}$ & $(0.0390)$ & $0.257^{* * *}$ & $(0.0404)$ & -0.068 & $(0.0428)$ \\
\hline DT2 & $-0.204^{* * *}$ & $(0.041)$ & $0.659^{* * *}$ & $(0.051)$ & $-0.397^{* * *}$ & $(0.0423)$ \\
\hline DT3 & & & $-0.195^{* * *}$ & $(0.0422)$ & & \\
\hline Number of Firms & $0.002^{* * *}$ & $(0.0001)$ & $0.002^{* * *}$ & $(0.0001)$ & $0.0010^{* * *}$ & $(0.0001)$ \\
\hline Average Firm size & $0.003^{* * *}$ & $(0.0002)$ & $0.002^{* * *}$ & $(0.0002)$ & $0.001^{* * *}$ & $(0.0003)$ \\
\hline Export Share & $0.006^{* * *}$ & $(0.0012)$ & $0.006^{* * *}$ & $(0.0008)$ & $0.008^{* * *}$ & $(0.0011)$ \\
\hline R\&D Employment & $0.090^{* * *}$ & $(0.0089)$ & $0.068^{* * *}$ & $(0.0089)$ & $0.078^{* * *}$ & $(0.0098)$ \\
\hline Population Density & $0.256^{* * *}$ & $(0.0191)$ & $0.232^{* * *}$ & $(0.0177)$ & $0.159^{* * *}$ & $(0.0177)$ \\
\hline Sectoral Specialization 2 & -0.179 & $(0.2426)$ & $-0.613^{* * *}$ & $(0.2499)$ & $-1.487^{* * *}$ & $(0.2573)$ \\
\hline Sectoral Specialization 3 & $-3.576^{* * *}$ & $(0.1933)$ & $-4.117^{* * *}$ & $(0.2047)$ & $-3.226^{* * *}$ & $(0.2008)$ \\
\hline Sectoral Specialization 4 & $-0.335^{* *}$ & $(0.1933)$ & $0.268^{*}$ & $(0.1589)$ & $0.712^{* * *}$ & $(0.1570)$ \\
\hline$(\text { Sectoral Specialization } 2)^{2}$ & -0.026 & $(0.0191)$ & 0.010 & $(0.0197)$ & $0.081^{* * *}$ & $(0.0203)$ \\
\hline$(\text { Sectoral Specialization } 3)^{2}$ & $0.317^{* * *}$ & $(0.0187)$ & $0.386^{* * *}$ & $(0.0196)$ & $0.282^{* * *}$ & $(0.0194)$ \\
\hline$(\text { Sectoral Specialization } 4)^{2}$ & $0.052^{* * *}$ & $(0.0164)$ & -0.005 & $(0.0167)$ & $-0.060^{* * *}$ & $(0.0167)$ \\
\hline Ellison-Glaeser 2 & $0.044^{* * *}$ & $(0.0049)$ & $0.042^{* * *}$ & $(0.0051)$ & $0.041^{* * *}$ & $(0.0057)$ \\
\hline Ellison-Glaeser 3 & -0.004 & $(0.0131)$ & $-0.037^{* *}$ & $(0.0138)$ & $0.027^{*}$ & $(0.0146)$ \\
\hline Ellison-Glaeser 4 & $0.067^{* * *}$ & $(0.0164)$ & $0.108^{* * *}$ & $(0.0170)$ & $0.066^{* * *}$ & $(0.0179)$ \\
\hline$(\text { Ellison-Glaeser } 2)^{2}$ & $-0.001^{* * *}$ & $(0.0001)$ & $-0.001^{* * *}$ & $(0.0001)$ & $-0.001^{* * *}$ & $(0.0001)$ \\
\hline$(\text { Ellison-Glaeser } 3)^{2}$ & $-0.003^{* * *}$ & $(0.0005)$ & $-0.002^{* * *}$ & $(0.0004)$ & $-0.002^{* * *}$ & $(0.0005)$ \\
\hline$(\text { Ellison-Glaeser } 4)^{2}$ & 0.001 & $(0.0008)$ & -0.0002 & $(0.0008)$ & -0.0007 & $(0.0008)$ \\
\hline \multicolumn{7}{|l|}{ Probit (ZIP) } \\
\hline Start-up (High-Tech) & $0.696^{* * *}$ & $(0.2588)$ & $0.809^{* * *}$ & $(0.2395)$ & $0.745^{* * *}$ & $(0.2694)$ \\
\hline Start-up (all) & $-0.089^{* * *}$ & $(0.0226)$ & $-0.083^{* * *}$ & $(0.0208)$ & $-0.089^{* * *}$ & $(0.0244)$ \\
\hline $\mathrm{DiDiD}=\mathrm{DT} 1-\mathrm{DT} 2$ & $0.538^{* * *}$ & $(0.0480)$ & $0.453^{* * *}$ & $(0.0502)$ & $0.330^{* * *}$ & $(0.0537)$ \\
\hline DiDiD2 = DT1 - DT3 & & & $-0.407^{* * *}$ & $(0.0579)$ & & \\
\hline Spatial Filter (joint) & \multicolumn{2}{|c|}{$\chi^{2}(74)=14167.1^{* * *}$} & \multicolumn{2}{|c|}{$\chi^{2}(66)=11149.9^{* * *}$} & \multicolumn{2}{|c|}{$\chi^{2}(67)=11386.9^{* * *}$} \\
\hline No. of obs. & \multicolumn{2}{|l|}{$818^{a}$} & \multicolumn{2}{|l|}{836} & \multicolumn{2}{|l|}{$812^{a}$} \\
\hline
\end{tabular}

Notes: $* * * * *, *$ indicate statistical significance at the 1, 5 and $10 \%$ level. Standard errors in brackets. Specialization and Ellison-Glaeser indices: $2=$ manufacturing, $3=$ business-related services, $4=$ household-related services. Dummy variables: D1 = winners, D2 = participants (in the BRC2 sample: D2= BPC winners, D3 = further participants). DT1 to DT3 indicate the DiD interaction term calculated as the product of the level dummies and the common time trend T. Number of observations: ${ }^{a}=$ BPC winners dropped in sample BRC1, BRC winners dropped in sample BPC.

jointly and strongly significant, and thus indicate that spatial elements help in improving the overall model fit. Nevertheless, the parameter size and significance of the DiD terms is unchanged in the spatially augmented model. The marginal effects (measured as elastici- 
ties) of the DiDiD term comparing BRC and BRC winners is still -0.33 (compared to -0.28 in the non-spatial model), while the positive BRC effect relative to further participants is 0.57 (compared to 0.61 ).

\section{Conclusion}

In this paper, we analysed the performance of winning regions of Germany's well-known BioRegio and BioProfile contests. These contests marked a milestone in the attempt to allocate public R\&D funds in a competitive way, which strongly emphasizes the role of geographic proximity in knowledge creation, and to push collaborative R\&D projects in leading biotechnology clusters. Although the BioRegio contest was one of the major attempts of the German Federal Government to narrow the gap between with those countries leading in the application of biotechnological knowledge, so far little is known about its innovation and economic impact during the treatment period and in the posttreatment period. We tackled this issue by analysing two important measures of R\&D performance, namely, the number of patent applications in biotechnology, and the number of publicly funded R\&D projects. We applied a Difference-in-Difference estimation within a generalized linear model framework, based on data for 426 German NUTS-3 districts. Our estimation strategy allows to control for observable and time-invariant unobservable differences in the pre-funding period, which also drive $R \& D$ performance in the treatment and post-treatment period.

In order to identify the effect of the BioRegio and BioProfile contests on regional R\&D activity in the field of biotechnology, we evaluate, in first place, the research outcomes of winning regions against non-winning participants. The choice of this first comparison is motivated by the need to reduce the potential self-selection bias stemming from a nonrandom selection into treatment. Our results show that BRC winners and (to a lesser extent) BPC winners outperform non-winning participants during the treatment period. Exclusive funding, as well as stimulating effects of the "winner" label, seems to work for them in the short run. Given the sequential starting dates of the BioRegio and BioProfile contests, we are also able to compare the performance of BRC and BPC winners during a limited treatment period. In this case, the results highlight two empirical facts: on the on hand, after being selected, the BRC winners significantly increased their relative performance in raising public $\mathrm{R} \& \mathrm{D}$ projects; on the other hand, they do not outperform $\mathrm{BPC}$ winners in terms of patent applications during the treatment period, although both groups show a significant positive effect compared to non-winning participants (in both

competitions). The catching up of BPC winners to BRC winners can be explained in 
particular by their smaller absolute size in terms of the number of patent applications prior to the treatment, for which we control in our Difference-in-Difference approach. Thus, among the candidates in the BRC, the jury clearly picked heavyweights, compared to the dynamically growing, but smaller 'rising stars'. The latter were selected in the second stage, namely the BPC. This finding provides further empirical evidence that the outcome of both the BRC and BPC are the obvious result of "picking the winners", as argued, for example, by Dohse (2000).

In contrast with these positive effects during the treatment period, we do not find significant outcome effects of public R\&D grants for BRC winners in the post-treatment period. This result is striking, and may indicate that the success of the BRC seems to be only of a temporary manner. However, there is some evidence of positive longterm effects for collaborative R\&D projects. Moreover, the reader has to note that our findings may be limited by the quality of the indicator used: in fact, we are only able to compare the number of raised public R\&D grants, which may actually follow different allocation guidelines than the one of serving the most successful regions (e.g., distributive arguments). This result is also supported by the analysis of the spatial distribution of the outcome variables. Finally, the absence of long-term effects of BRC may also driven by the fact that non-winning regions have increased their efforts to establish networks between biotech-related firms and research units. In fact, ten more BioRegios were formed by 2005 after the BioRegio contest, and several Federal States have promoted significantly the emergence of BioRegions locally. These efforts are clearly intended in the contest of a cooperation approach to R\&D policy.

Future analyses will thus be needed to consider additional market-related measures for R\&D performance assessment (e.g., the share of turnover with new biotech products, or employment in biotechnology-related firms). These further indicators will allow academic research to provide more thorough assessments of the success rate of cluster-based $\mathrm{R} \& \mathrm{D}$ policies, which are currently widely applied at the national and regional level.

\section{References}

[1] Ai, D. and Norton, E., 2003. Interaction Terms in Logit and Probit Models. Economics Letters 80, 123-129.

[2] Almeida, P. and Kogut, B., 1999. Localization of Knowledge and the Mobility of Engineers in Regional Networks. Management Science 45, 905-917.

[3] Anselin, L., 1988. Spatial Econometrics: Methods and Models, Dodrecht. 
[4] Anselin, L., Varga, A. and Acs, Z., 1997. Local Geographic Spillovers between University Research and High Technology Innovations. Journal of Urban Economics 42, 422-448.

[5] Acs, Z., Audretsch, D. and Feldman, M., 1993. R\&D Spillovers and Recipient Firm Size. Review of Economics Statistics 76, 336-340.

[6] Audretsch, D.B. and Feldman, M.P., 1996. R\&D Spillovers and the Geography of Innovation and Production. American Economic Review 86, 630-640.

[7] Baptista, R. and Swann, P., 1998. Do firms in clusters innovate more? Research Policy 27(5), 525-540.

[8] Baptista, R., 2000. Does Innovation diffuse faster within geographical cluster? International Journal of Industrial Organization 18, 515-535.

[9] BMBF - Bundesministerium für Bildung und Forschung, 2006. Bundesforschungsbericht 2006. Internet: www.bmbf.de/pub/bufo2006.pdf.

[10] Czarnitzki, D., B. Ebersberger and A. Fier, 2007. The Relationship between R\&D Collaboration, Subsidies and R\&D performance: Empirical Evidence from Finland and Germany. Journal of Applied Econometrics 22, 1347-1366.

[11] Cooke, P., Stähler, T. and Dohse, D., 2007. Evaluation der Fördermaßnahmen BioRegio und BioProfile, Third-party research on demand of Federal Ministry of Education and Research, FKZ: 0313708.

[12] Dauth, W., 2010. Agglomeration and regional employment growth. IAB Discussion Paper No. 201007.

[13] Dohse, D., 2000. Technology Policy and the Regions - The Case of the BioRegio Contest. Research Policy 29, 1111-1133.

[14] Engel, D. and Heneric, O., 2005. Biotechnologiegründungen im Ruhrgebiet Eine vergleichende Analyse, RWI: Materialien, Heft 21, Essen.

[15] Engel, D. and Heneric, O., 2008. Legal Frameworks and Public Support in the Biotechnology Industry, in H. Patzelt and T. Brenner, Handbook of BiotechEntrepreneurship, International Handbook Series on Entrepreneurship, Vol. 4, Springer: Berlin, 249-274.

[16] Falck, O., S. Kipar and S. Heblich (2010). Industrial Innovation: Direct Evidence from a Cluster-Oriented Policy, Regional Science and Urban Economics, in press.

[17] Fornahl, D., Broekel, T. and Boschma, R., 2010. What drives patent performance in German biotech firms? The impact of R\&D subsidies, knowledge networks and their location. Papers in Evolutionary Economic Geography No. 1009, Utrecht University. 
[18] Greene, W. 2003. Econometric Analysis, Prentice Hall.

[19] Griffith D., 2000. A linear regression solution to the spatial autocorrelation problem. Journal of Geographical Systems 2, 141-156.

[20] Griffith, D., 2003. Spatial Autocorrelation and Spatial Filtering. Berlin.

[21] Griffith D., 2006. Hidden negative spatial autocorrelation, Journal of Geographical Systems 8, 335-355.

[22] Griliches, Z., 1990. Patent Statistics as Economic Indicators: A Survey, Journal of Economic Literature XXVIII, 1661-1707.

[23] Grimpe, C. and Patuelli, R., 2010. Regional Knowledge Production in Nanomaterials: A Spatial Filtering Approach. The Annals of Regional Science, in press.

[24] Klepper, S., 2007. Disagreements, Spinoffs, and the Evolution of Detroit as the Capital of the U.S. Automobile Industry, Management Science 53, 616-631.

[25] Lecocq, C., Leten, B., Kusters, J. and van Looy, B., 2009. Do Firms benefit fomr being present in Technology Clusters? Evidence from Firms active in the Field of Biotechnology. Paper presented at the RSA Annual Conference 2009, Leuven, Belgium.

[26] Marshall, A., 1890. Principles of Economics, London et al.: Macmillan \& Co.

[27] Martin, P., Mayer, T. and Mayneris, F., 2010. Public Support to Clusters: A Firm Level Study of French Local Productive Systems', Regional Science and Urban Economics, 2010, in press.

[28] OECD, 2006. Innovation in Pharmaceutical Biotechnology. Comparing National Innovation Systems at the Sectoral Level, Paris.

[29] Patuelli, R., Schanne, N., Griffith, D. and Nijkamp, P., 2010. Persistence of Regional Unemployment: Application of a Spatial Filtering Approach to Local Labour Markets in Germany. Working Paper No. 49-09, The Rimini Centre for Economic Analysis.

[20] Puhani, P., 2008. The Treatment Effect, the Cross Difference, and the Interaction Term in Nonlinear "Difference-in-Differences" Models. IZA DP No. 3478.

[31] Vuong, Q., 1989. Likelihood ratio tests for model selection and non-nested hypotheses. Econometrica 57, 307-333.

[32] Wolf, H., Michelsen, C. and Schwartz, M., 2010. Regional Entrepreneurial Opportunities in the Biotech Industry. IWH Discussion Paper No. 25.

[33] Zucker, L. G., Darby, M. R., 2006. Movement of star scientists and engineers and high-tech firm entry. National Bureau of Economic Research, Working Paper 12172. 
Appendix

A.1 Additional tables and figures 
Table A1: List of regions in the BioRegio and BioProfile contests

\begin{tabular}{|c|c|c|c|c|}
\hline ID & Name & $\begin{array}{l}\text { BioRegio } \\
\text { Winner }\end{array}$ & $\begin{array}{l}\text { BioRegio } \\
\text { Non-Winner }\end{array}$ & $\begin{array}{l}\text { BioProfile } \\
\text { Winner }\end{array}$ \\
\hline 1002 & Kiel (KS) & 0 & 1 & 0 \\
\hline 1003 & Luebeck (KS) & 0 & 1 & 0 \\
\hline 2000 & Hamburg (KS) & 0 & 1 & 0 \\
\hline 13003 & Rostock (KS) & 0 & 1 & 0 \\
\hline 13001 & Greifswald (KS) & 0 & 1 & 0 \\
\hline 3405 & Wilhelmshaven (KS) & 0 & 1 & 0 \\
\hline 3403 & Oldenburg (KS) & 0 & 1 & 0 \\
\hline 4011 & Bremen (KS) & 0 & 1 & 0 \\
\hline 4012 & Bremerhaven & 0 & 1 & 0 \\
\hline 3241 & Region Hannover & 0 & 1 & 1 \\
\hline 3201 & Hannover (KS) & 0 & 1 & 1 \\
\hline 3101 & Braunschweig (KS) & 0 & 1 & 1 \\
\hline 3152 & Göttingen & 0 & 1 & 1 \\
\hline 5124 & Wuppertal (KS) & 1 & 0 & 0 \\
\hline 5111 & Düsseldorf (KS) & 1 & 0 & 0 \\
\hline 5315 & Köln (KS) & 1 & 0 & 0 \\
\hline 5313 & Aachen (KS) & 1 & 0 & 0 \\
\hline 5316 & Leverkusen (KS) & 1 & 0 & 0 \\
\hline 5354 & Aachen & 1 & 0 & 0 \\
\hline 5358 & Düren & 1 & 0 & 0 \\
\hline 5314 & Bonn (KS) & 1 & 0 & 0 \\
\hline 6534 & Marburg-Biedenkopf & 0 & 1 & 0 \\
\hline 6531 & Gießen & 0 & 1 & 0 \\
\hline 6414 & Wiesbaden (KS) & 0 & 1 & 0 \\
\hline 6412 & Frankfurt (KS) & 0 & 1 & 0 \\
\hline 7315 & Mainz (KS) & 0 & 1 & 0 \\
\hline 6411 & Darmstadt (KS) & 0 & 1 & 0 \\
\hline 6413 & Offenbach (KS) & 0 & 1 & 0 \\
\hline 6436 & Main-Taunus & 0 & 1 & 0 \\
\hline 6438 & Offenbach & 0 & 1 & 0 \\
\hline 8221 & Heidelberg (KS) & 1 & 0 & 0 \\
\hline 8222 & Mannheim (KS) & 1 & 0 & 0 \\
\hline 7314 & Ludwigshafen (KS) & 1 & 0 & 0 \\
\hline 7316 & Neustadt a. d. W. (KS) & 1 & 0 & 0 \\
\hline 8111 & Stuttgart (KS) & 0 & 1 & 1 \\
\hline 8116 & Esslingen & 0 & 1 & 1 \\
\hline 8416 & Tübingen & 0 & 1 & 1 \\
\hline 8415 & Reutlingen & 0 & 1 & 1 \\
\hline 8417 & Zollernalbkreis & 0 & 1 & 1 \\
\hline 8311 & Freiburg (KS) & 0 & 1 & 0 \\
\hline 8421 & Ulm (KS) & 0 & 1 & 0 \\
\hline 9162 & München (KS) & 1 & 0 & 0 \\
\hline 9188 & Starnberg & 1 & 0 & 0 \\
\hline 9362 & Regensburg (KS) & 0 & 1 & 0 \\
\hline 16053 & Jena $(\mathrm{KS})$ & 1 & 0 & 0 \\
\hline 15202 & Halle (KS) & 0 & 1 & 0 \\
\hline 14365 & Leizpig (KS) & 0 & 1 & 0 \\
\hline 15261 & Merseburg-Querfurt & 0 & 1 & 0 \\
\hline 15265 & Saalkreis & 0 & 1 & 0 \\
\hline 15154 & Bitterfeld & 0 & 1 & 0 \\
\hline 11000 & Berlin (KS) & 0 & 1 & 1 \\
\hline 12065 & Oberhavel & 0 & 1 & 1 \\
\hline 12069 & Postdam-Mittelmark & 0 & 1 & 1 \\
\hline 12072 & Teltow-Fläming & 0 & 1 & 1 \\
\hline 12054 & Potsdam (KS) & 0 & 1 & 1 \\
\hline
\end{tabular}


Table A2: Definition of the Biotech sector based on IPC classes

\begin{tabular}{|c|c|}
\hline Patent class & Title \\
\hline $\mathrm{A} 01 \mathrm{H} 1 / 00$ & Processes for modifying genotypes \\
\hline $\mathrm{A} 01 \mathrm{H} 4 / 00$ & Plant reproduction by tissue culture techniques \\
\hline A61K 38/00 & Medicinal preparations containing peptides \\
\hline A61K 39/00 & Medicinal preparations containing antigens or antibodies \\
\hline A61K 48/00 & $\begin{array}{l}\text { Medicinal preparations containing genetic material which is inserted into cells of the living } \\
\text { body to treat genetic diseases; Gene therapy }\end{array}$ \\
\hline $\mathrm{C} 02 \mathrm{~F} 3 / 34$ & $\begin{array}{l}\text { Biological treatment of water, waste water, or sewage: characterised by the } \\
\text { micro-organisms used }\end{array}$ \\
\hline C07G 11/00 & Compounds of unknown constitution: antibiotics \\
\hline C07G 13/00 & Compounds of unknown constitution: vitamins \\
\hline C07G 15/00 & Compounds of unknown constitution: hormones \\
\hline $\mathrm{C} 07 \mathrm{~K} 4 / 00$ & $\begin{array}{l}\text { Peptides having up to } 20 \text { amino acids in an undefined or only partially defined sequence; } \\
\text { Derivatives thereof }\end{array}$ \\
\hline C07K 14/00 & $\begin{array}{l}\text { Peptides having more than } 20 \text { amino acids; Gastrins; Somatostatins; Melanotropins; } \\
\text { Derivatives thereof }\end{array}$ \\
\hline $\mathrm{C} 07 \mathrm{~K} 16 / 00$ & Immunoglobulins, e.g. monoclonal or polyclonal antibodies \\
\hline $\mathrm{C} 07 \mathrm{~K} 17 / 00$ & Carrier-bound or immobilised peptides; Preparation thereof \\
\hline C07K 19/00 & Hybrid peptides \\
\hline $\mathrm{C} 12 \mathrm{M}$ & Apparatus for enzymology or microbiology \\
\hline $\mathrm{C} 12 \mathrm{~N}$ & Micro-organisms or enzymes; compositions thereof \\
\hline $\mathrm{C} 12 \mathrm{P}$ & $\begin{array}{l}\text { Fermentation or enzyme-using processes to synthesise a desired chemical compound or } \\
\text { composition or to separate optical isomers from a racemic mixture }\end{array}$ \\
\hline $\mathrm{C} 12 \mathrm{Q}$ & $\begin{array}{l}\text { Measuring or testing processes involving enzymes or micro-organisms; compositions or test } \\
\text { papers therefor; processes of preparing such compositions; condition-responsive control in } \\
\text { microbiological or enzymological processes }\end{array}$ \\
\hline $\mathrm{C} 12 \mathrm{~S}$ & $\begin{array}{l}\text { Processes using enzymes or micro-organisms to liberate, separate or purify a pre-existing } \\
\text { compound or composition processes using enzymes or micro-organisms to treat textiles or } \\
\text { to clean solid surfaces of materials }\end{array}$ \\
\hline G01N 27/327 & $\begin{array}{l}\text { Investigating or analysing materials by the use of electric, electro-chemical, or magnetic } \\
\text { means: biochemical electrodes }\end{array}$ \\
\hline G01N 33/53* & $\begin{array}{l}\text { Investigating or analysing materials by specific methods not covered by the preceding } \\
\text { groups: immunoassay; biospecific binding assay; materials therefore }\end{array}$ \\
\hline G01N 33/54* & $\begin{array}{l}\text { Investigating or analysing materials by specific methods not covered by the preceding } \\
\text { groups: double or second antibody: with steric inhibition or signal modification: with an } \\
\text { insoluble carrier for immobilising immunochemicals: the carrier being organic: synthetic } \\
\text { resin: as water suspendable particles: with antigen or antibody attached to the carrier via a } \\
\text { bridging agent: Carbohydrates: with antigen or antibody entrapped within the carrier }\end{array}$ \\
\hline G01N 33/55* & $\begin{array}{l}\text { Investigating or analysing materials by specific methods not covered by the preceding } \\
\text { groups: the carrier being inorganic: Glass or silica: Metal or metal coated: the carrier being } \\
\text { a biological cell or cell fragment: Red blood cell: Fixed or stabilised red blood cell: using } \\
\text { kinetic measurement: using diffusion or migration of antigen or antibody: through a gel }\end{array}$ \\
\hline G01N 33/57* & $\begin{array}{l}\text { Investigating or analysing materials by specific methods not covered by the preceding } \\
\text { groups: for venereal disease: for enzymes or isoenzymes: for cancer: for hepatitis: involving } \\
\text { monoclonal antibodies: involving limulus lysate }\end{array}$ \\
\hline G01N 33/68 & $\begin{array}{l}\text { Investigating or analysing materials by specific methods not covered by the preceding } \\
\text { groups: involving proteins, peptides or amino acids }\end{array}$ \\
\hline G01N 33/74 & $\begin{array}{l}\text { Investigating or analysing materials by specific methods not covered by the preceding } \\
\text { groups: involving hormones }\end{array}$ \\
\hline G01N 33/76 & $\begin{array}{l}\text { Investigating or analysing materials by specific methods not covered by the preceding } \\
\text { groups: human chorionic gonadotropin }\end{array}$ \\
\hline G01N 33/78 & $\begin{array}{l}\text { Investigating or analysing materials by specific methods not covered by the preceding } \\
\text { groups: thyroid gland hormones }\end{array}$ \\
\hline G01N 33/88 & $\begin{array}{l}\text { Investigating or analysing materials by specific methods not covered by the preceding } \\
\text { groups: involving prostaglandins }\end{array}$ \\
\hline G01N 33/92 & $\begin{array}{l}\text { Investigating or analysing materials by specific methods not covered by the preceding } \\
\text { groups: involving lipids, e.g. cholesterol }\end{array}$ \\
\hline
\end{tabular}

Source: OECD (2005), p.32.

Notes: * = Those IPC codes also include subgroups up to one digit ( 0 or 1 digit). For example, in addition to the code G01N 33/53, the codes G01N 33/531, GO1N 33/532, etc. are included. 
Table A3: Biotech categories in PROFI database

\begin{tabular}{ll}
\hline \hline Code & Technology field \\
\hline \multicolumn{2}{l}{ Biotechnology } \\
$\mathrm{K}$ & Biotechnology \\
I19080 & Molecular Bioinformatics \\
\hline \hline
\end{tabular}

Notes: Own definition according to the technology field classification of the Leistungsplansystematik des Bundes. - The following activities have not been considered; "Projektstabskosten" (Code XX XX 90), "Projektbegleiter" (Code XX XX 91), "Beratungsgremien" (Code XX XX 92), "Programmevaluation" (Code XX XX 95).

Table A4: Descriptive statistics for total sample (Pre-, Treatment, Post-Treatment period)

\begin{tabular}{|c|c|c|c|c|c|}
\hline Variable & $\mathrm{N}$ & Mean & Std. Dev. & Min & $\operatorname{Max}$ \\
\hline Patents & 1317 & 20.722 & 63.124 & 0 & 1099 \\
\hline Projects (all) & 1317 & 10.845 & 40.491 & 0 & 673 \\
\hline Projects (collaborative) & 1317 & 6.008 & 22.881 & 0 & 445 \\
\hline Number of Firms & 1317 & 109.369 & 95.156 & 12 & 1071.5 \\
\hline Average Firm Size & 1317 & 131.899 & 112.608 & 37.47 & 1816.60 \\
\hline Export Share & 1257 & 27.334 & 13.233 & 0.15 & 96.19 \\
\hline R\&D Employment & 1317 & 2.206 & 1.305 & 0.40 & 13.55 \\
\hline Population Density & 1317 & 5.606 & 1.085 & 3.68 & 8.30 \\
\hline Sectoral Spezialization 2 & 1311 & 6.257 & 0.682 & 4.97 & 9.00 \\
\hline Sectoral Spezialization 3 & 1311 & 5.375 & 0.549 & 3.67 & 7.98 \\
\hline Sectoral Spezialization 4 & 1311 & 4.634 & 0.677 & 2.97 & 6.41 \\
\hline$(\text { Sectoral Specialization } 2)^{2}$ & 1311 & 39.616 & 9.128 & 24.73 & 81.04 \\
\hline$(\text { Sectoral Specialization } 3)^{2}$ & 1311 & 29.189 & 6.011 & 13.45 & 63.62 \\
\hline$(\text { Sectoral Specialization } 4)^{2}$ & 1311 & 21.933 & 6.377 & 8.83 & 41.11 \\
\hline Ellison-Glaeser 2 & 1311 & 21.301 & 10.671 & 2.075 & 68.631 \\
\hline Ellison-Glaeser 3 & 1311 & 6.362 & 3.847 & 1.205 & 2.933 \\
\hline Ellison-Glaeser 4 & 1311 & 3.231 & 2.703 & 0.273 & 21.630 \\
\hline$(\text { Ellison-Glaeser } 2)^{2}$ & 1311 & 567.76 & 566.38 & 4.304 & 4710.19 \\
\hline$(\text { Ellison-Glaeser } 3)^{2}$ & 1311 & 55.26 & 83.60 & 1.452 & 860.29 \\
\hline$(\text { Ellison-Glaeser } 4)^{2}$ & 1311 & 17.738 & 37.052 & 0.074 & 467.87 \\
\hline Start-up (High-Tech) & 1317 & 0.401 & 0.267 & 0.03 & 2.04 \\
\hline Start-up (all) & 1317 & 9.974 & 3.597 & 2.36 & 35.44 \\
\hline
\end{tabular}

Notes: For variable definition see text. Population Density and Sectoral Specialization in log-levels. Specialization and Ellison-Glaeser indices: 2 = manufacturing, 3 = business-related services, 4 = household-related services. 


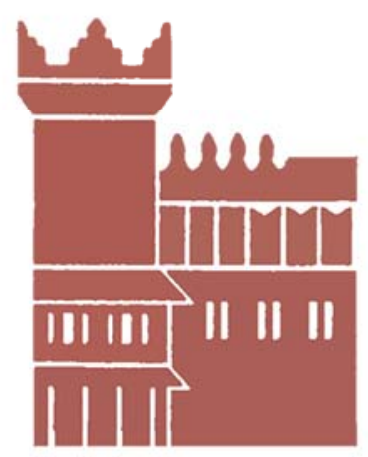

Alma Mater Studiorum - Università di Bologna DEPARTMENT OF ECONOMICS

Strada Maggiore 45

40125 Bologna - Italy

Tel. +39051 2092604

Fax +390512092664

http://www.dse.unibo.it 